\title{
Chapter 8 \\ Gates, Gaps, and Intergenerational Mobility: The Importance of an Even Start
}

\author{
Timothy M. (Tim) Smeeding
}

\begin{abstract}
This chapter focuses on how intergenerational mobility is affected by children's earliest life experiences from conception through preschool. These experiences are important because of their effects on outcomes later in life. One consequence is that intervening early is the most cost-effective way to put a child on course to pass through the gates that determine adult success and thereby reduce differences in mobility among children born in different circumstances. Using a life-cycle model, we examine the evidence on trends in factors that affect child development. The evidence we assess leads to the conclusion that opportunity and mobility are declining for lower and even middle class children as changes in family life, parenting practices, economic inequality, unresponsive social institutions, and increasingly economically homogeneous neighborhoods all point to a serious decline in the factors that are associated with greater mobility. We conclude that the decline in opportunity and mobility for current generations of American children is likely the biggest negative effect of the continuing U.S. inequality boom in income, wealth, and consumption. The paper ends by outlining a series of policies that would help restore opportunity in America by intervening early in the life course.
\end{abstract}

Keywords Intergenerational mobility (IGM) - Dynamic complementarity • Economic opportunity $\bullet$ Childhood outcomes $\bullet$ Human capital $\bullet$ Life-cycle model $\bullet$ Early childhood education $\bullet$ Childcare $\bullet$ Maternal health $\bullet$ Health care $\bullet$ Health insurance $\bullet$ Socioeconomic status (SES) • Unmarried mothers

\footnotetext{
The author thanks Educational Testing Service for its support in completing this paper. I also thank Henry Braun, Irwin Kirsch, and Andy Sum for their comments on an earlier draft. I also appreciate the comments of two referees, Steve Barnett and Bhash Mazumder, as well as the editorial help of Henry Braun, Larry Hanover, Deborah Johnson, and David Chancellor in completing this chapter. All errors of commission and omission are the responsibility of the author alone.
}

T.M.(T.) Smeeding $(\bowtie)$

University of Wisconsin-Madison, Madison, WI 53706, USA

I. Kirsch, H. Braun (eds.), The Dynamics of Opportunity in America,

DOI 10.1007/978-3-319-25991-8_8 


\section{Introduction: How Can We Make the Start More Even?}

Efforts to address economic opportunity are not enough as we seek to improve American society. That's because addressing economic opportunity does not deal with another problem: a lack of intergenerational mobility (IGM). Without more widespread opportunities to improve childhood outcomes and do a better job of building human capital for all children, we are not likely to see a systematic increase in relative social and economic intergenerational mobility-movement up (or down) in socioeconomic class within a family from one generation to the next (see, for instance, Jencks and Tach 2006; Smeeding 2015).

Policy makers concerned about IGM need to think about how to overcome barriers in order to create more opportunity for those left behind and how to make greater opportunity translate into more mobility. In the parlance of the Opportunity in America project, we need to open more gates to opportunity for more children. And we need to reduce the gaps in successful outcomes between the children of the haves and have-nots, with the latter passing through key transition points with positive momentum instead of confronting closed gates at each point, falling further and further behind.

To guide our analysis, we need a framework to map out progress in reducing barriers that inhibit equalizing opportunity and IGM. The traditional literature on IGM does not help us much in this task. Most scholarly discussions of IGM focus on the question of income mobility for children once they have reached adulthood. Some of these studies tell us overall mobility has not declined in recent decades, which is unsurprising for an economy where income gains were widespread and living standards rose across the distribution up until the early 1980s (compare Mazumder 2015 and Smeeding 2015 with Chetty et al. 2014). We also know from national and crossnational research that there is substantial "stickiness" at both the top and bottom of the U.S. IGM matrix of parental and child incomes, with about 35-40\% of children that start in families at the top or the bottom of the heap ending up there as adults (Jäntti et al. 2006). Finally, we know that the resource levels separating the poor from the rich have grown in magnitude since the inequality generation was born in the 1980s, meaning that even with constant mobility, the consequences of ending up at one end or the other of the adult outcome distribution are much greater now because the dispersion in outcomes is much wider due to growing inequality in income and wealth.

If we are to advocate for policies to enhance opportunity and improve IGM for the next generation, we need to look at the factors affecting today's and tomorrow's children's chances at upward mobility, both in a relative and an absolute sense. A life-cycle approach begins to do this by setting up markers of success along the road to greater IGM from conception onward. By viewing IGM from this perspective, we are able to observe factors that increase or decrease equality of opportunity and mobility, and therefore, those that affect gates and gaps. These include both policies and institutions that open or close gates, and actions and choices made by individuals 
that either help to reduce opportunity gaps for themselves and their children or have the opposite effect-to widen them.

In this chapter, I focus on just a few steps along this continuum but the ones that I believe are the most important-those earliest in life. Increasingly, scientific evidence on child development and success focuses on the very earliest developmental periods (Aizer and Currie 2014; Mazumder et al. 2010). Thus we argue that worrying about a child's chances of success in life by starting with preschool is not starting too early but rather at least two or three steps too late. Indeed preschool is the final step along the life cycle that we address in this chapter.

We begin by asking what makes a difference early in life. We consider just a sample of the evidence on child differences by social and economic origin that is accumulating in all social and behavioral science fields, as well as the brain sciences. We then review recent changes in the five most important factors that propel or hinder progress at early (and later) life stages: family structure and stability; parenting practices; economic inequality; social institutions; and neighborhoods and the role of place. These factors interact with one another and together strongly influence both opportunity and mobility. We also discuss how these dynamics will be playing out in a very different world, one in which there is no racial or ethnic majority but ever-larger numbers of children of color. ${ }^{1}$

The goal is to produce a healthy, active, curious, happy, and engaged child for the first day of elementary school. With this in mind we examine how children are affected by these forces in three early life stages: prenatal and family birth status; early home life, health, and childcare during ages 6 months to 3 or 4 years; and family life, neighborhood, and preschool during ages 4-6. Evidently, there are large gaps in outcomes related to school readiness that are systematically linked to the contextual factors listed above. In particular, we need to determine if the gap between the top and bottom of the child well-being distribution has narrowed or widened along this path. Finally, we will conclude with some suggestions on policy levers that can increase the chances of success for children born to disadvantage.

Throughout the chapter, we must ask what the "proper" roles of government are and society is in this process. How might we target public investment in children's (and in some cases their parents') development-in their education, health, safety, and so on-to compensate for lower private investment and less capable parenting? Resources can play a significant role at strategic transition points in the life cycle (i.e., places where more investment on the part of parents or institutions can make a big difference in children's outcomes). Some come early and are addressed here, such as parent-child interactions and the development of cognitive skills and character (grit, social competency, perseverance, and good habits), while others come later in life. The latter include schooling choices, paying for college, providing funding to enable acceptance of an unpaid internship, direct job provision in family firms (nepotism), or helping a first entrance into the housing market. But in all cases, disparities in child outcomes appear at the earliest stages of life. And there is

\footnotetext{
${ }^{1}$ See, for instance, Frey 2014 and the section entitled "The 5 Big Factors That Determine Early Development."
} 
ever mounting evidence that the early childhood period, when the brain is most malleable, is the time where interventions for at-risk children might be most cost-effective (Heckman and Mosso 2014).

The scope of this investigation includes not only the poor but also the lower middle class. Stagnant earnings and flat or falling incomes, such as those that most workers are now experiencing, suggest that the barriers we identify are a worry for strapped middle classes, not just poor families with children (Shapiro 2015). There is a need for wages and incomes to rise in real terms for those now in the middle class. There is a difference between making a life on a poverty budget that provides just enough to barely shelter, feed, and clothe one's children, and one that is based on a budget sufficient to support a "well raised" child. In this regard, the important issue of the split in these costs between parents/families and the public sector and even the private sector arises. ${ }^{2}$ Hence mobility is an issue for middle class families, not just the poor.

The present study is not simply an academic one: Opportunity and social mobility are growing popular and political issues. The belief in the opportunity to reach the American Dream is being seriously questioned today. ${ }^{3}$ It once was a strongly and widely held view that if you worked hard and played by the rules, you could get ahead in America. But that has changed. Today, only $42 \%$ of Americans agree that if you work hard, you'll get ahead, while just less than half (48\%) believe that was once but no longer true. Also notably, less than one-third of Black Americans believe that hard work gets you ahead, while one-seventh never believed this was true. Indeed, flat incomes indicate hard work and recovery from the Great Recession have not yet paid off for the middle classes.

More to the point for IGM analysis, most Americans (55\%) believe that one of the biggest problems in the country is that not everyone is given an equal chance to succeed in life. And according to Galston (2014), other recent surveys have shown the same result - parents' confidence in their children being better off than they are is at or near the lowest point ever recorded:

(W)hen the August 2014 NBC/WSJ poll asked "Do you feel confident or not confident that life for our children's generation will be better than it has been for us?", only 21 percent expressed confidence, down from $30 \%$ in 2012. During the same month, the CBS poll asked, "Do you think the future of the next generation of your family will be better, worse, or about the same as your life today?", only $23 \%$ responded "better" compared to fully $50 \%$ who said "worse."

In June, CNN/ORC found that only $34 \%$ of respondents believed that most children would grow up to be better off than their parents, while $63 \%$ expected the children to be worse off. And the Heldrich Center at Rutgers' Bloustein School found in August that only $16 \%$ of Americans expect job, career, and employment opportunities to be better for the

\footnotetext{
${ }^{2}$ Kirkegaard (2015) suggests that public finance support for U.S. children is amassed mainly in the tax code and therefore supports rich children much more than poor ones. Absent changes in federal funding to favored new investment in children, new methods to pay must be found. The new institution of Social Impact Bonds (SIBs), where the public sector pays back private investments in outcomes that reduce future public costs, might help in such instances. For more, see Liebman (2011) and Costa (2014).
}

${ }^{3}$ Data collected in July and August 2014; Jones et al. 2014. 
next generation than for the current generation, compared with $40 \%$ in November of 2009, just months after the official end of the Great Recession (Galston 2014).

And families are not just imagining retrenchment, they are living it. A recent Brookings Institution report (Shapiro 2015) notes that in 2000, $16 \%$ of households were headed by people without high school diplomas, and an additional $51 \%$ were headed by people without college degrees. From 2002 to 2012, the median income of the group without high school diplomas declined at an average annual rate of $2.4 \%$ across age cohorts year after year; the median income of the group without college degrees fell at an average annual rate of $1 \%$ across age cohorts year after year. That tells us that two-thirds of American households have suffered persistent income losses from 2002 to 2012, a period that included eight years of economic "expansion" and two years of serious recession.

Overall then, it appears that most Americans express significant concerns about the economic future of their children and themselves. But they also are questioning their beliefs in America being an equal opportunity society, a principle widely thought by many to be our highest social value. ${ }^{4}$ Restoring opportunity in America has to become an important and continuing national priority.

\section{What Makes a Difference Early in Life?}

In this section, we introduce the life-cycle model. We then provide a brief review of what we know about early influences on health, behavior, and learning, establishing the following:

- Child development starts at conception, influenced by prenatal health and intrauterine environment, and these factors have important longer-term effects, according to evidence from test of the fetal origins hypothesis.

- Brain development differs between rich and poor children from conception onward.

- Health status, health care access, and parenting are the keys to successful early child development (after birth but before formal preschool).

- Poor health and bad birth outcomes make it harder for such children to catch up with others as life progresses according to the "dynamic complementarity" hypothesis.

- Difficulties persist in providing high-quality preschool experiences for poor children.

\footnotetext{
4" [Only] in America is equality of opportunity a virtual national religion, reconciling individual liberty - the freedom to get ahead and 'make something of yourself' - with societal equality. It is a philosophy of egalitarian individualism. The measure of American equality is not the income gap between the poor and the rich, but the chance to trade places" Reeves (2014).
} 


\section{Gates and Gaps and the Life-Cycle Model}

In a recent pair of cross-national research volumes, the authors and editors took the life-cycle approach to studying the relationship of parental education and income to child outcomes from birth to age 30 (Smeeding et al. 2011a; Ermisch et al. 2012). Figure 8.1 summarizes their model of the process from birth to adulthood for one generation, moving across six life stages from origin (parental socioeconomic status, or SES) to destination (children's adulthood SES). Parental investments and social institutions affect each step, where intermediate gains or losses are measured in multiple domains.

This structure allowed us to combine evidence from different cohorts at different times, with every outcome in every country being ranked by adult educational differences. Taken as a whole, these studies suggest a powerful effect of parental SES on child outcomes in health, cognitive testing, sociobehavioral outcomes, school achievement, and adult social and economic outcomes. Examination of standardized outcomes across 11 countries found a definite and universal pattern: the higher

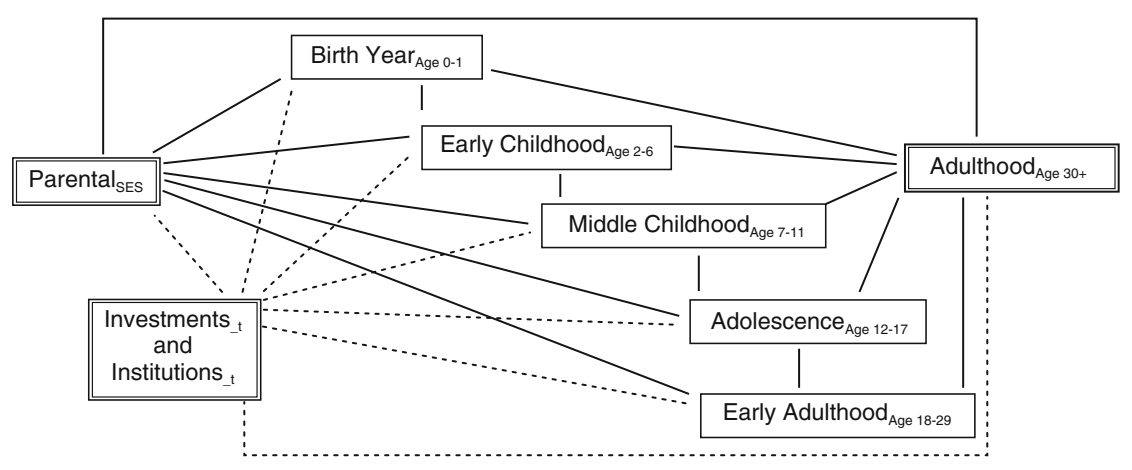

Table A. Variable Definitions and Examples of Proposed Measures at Different Points in the Life Course

\begin{tabular}{|c|}
\hline $\begin{array}{l}\text { Parental SocioEconomic Variables (Parental } \\
\text { Mes) } \\
\text { Measures: Education, Income, Earnings, SES, Occupation, Wealth, Employment }\end{array}$ \\
\hline $\begin{array}{l}\text { Childhood/Early Adulthood Life Stages Birth Year (age 0-1), Early Childhood (age 2-6), } \\
\text { Middle Childhood (age 7-11), Adolescence (age 12-17), Early Adulthood (age 18-29) } \\
\text { Measures: Educational attainment, cognitive measures, socio-emotional behavior, } \\
\text { employment/labor market, health/physical }\end{array}$ \\
\hline $\begin{array}{l}\text { Investments }{ }_{-t} \text { and Institutions } s_{t} \\
\text { Are assumed to be different public and private investments and institutions } \\
\text { contributing to children's development that vary by country. }\end{array}$ \\
\hline $\begin{array}{l}\text { Adulthood (Age } \mathbf{3 0 +} \text { ) } \\
\text { Measures: Child SES, Income, Education, Employment, Labor Market Attachment }\end{array}$ \\
\hline
\end{tabular}

Fig. 8.1 A model of intergenerational transmission of advantage by life stage (Ermisch et al. 2012) 
the adult SES as measured by educational attainment, the larger the positive effect on children's outcomes as they crossed each transition point.

The gaps among children ranked by parental education were observed from birth onward and did not diminish as they got older. Although in some cases the gaps widened, this was not always the case. Notably, the slopes of the relationships between parental SES and child outcomes were most steep in the United States. ${ }^{5}$

The same structure facilitates the assessment of how various cohorts of United States children will be affected by growing gaps in parental SES (education, earnings, wealth, and income). In this chapter we concentrate only on the first two stages in Fig. 8.1: conception and birth through early childhood. ${ }^{6}$

\section{What We Know about Early Influences on Health, Behavior, and Learning: A Very Brief Review}

Child development starts at conception. The fetal origins hypothesis first suggested by Barker (1995) hypothesizes that pre-birth experiences have long-term effects on health. Ever mounting evidence suggests that maternal impoverishment during the prenatal period has a substantial causal impact on infant health and long-term outcomes (Aizer and Currie 2014). Behaviors (smoking, drinking, substance abuseeach holding other factors constant) and exposure to toxins all exert a negative influence on in-utero child health, full-term birth, birth weight, and early child wellbeing (Lien and Evans 2005). Exposure to harmful environmental factors such as pollution, violence, and stress also take their toll on mothers and children alike (Currie et al. 2009; Currie and Walker 2011). Nutritional and health effects in-utero are also important to long-term outcomes for children-the findings of multiple studies suggest the growing importance of such effects (Mazumder et al. 2010, 2015; Almond and Mazumder 2011; Almond et al. 2012; Almond and Currie 2011).

Mothers born in a high-disease environment were also more likely than other women to have low-birth-weight offspring and to be suffering from diabetes when they gave birth, suggesting a strong intergenerational environmental component to poor health (Almond et al. 2011; Aizer and Cunha 2012; Smeeding 2015). Disadvantaged women also have greater exposure to, and are more susceptible to, contagions such as seasonal influenza. Hence, they may be disproportionately affected by pandemics which, in turn, can negatively affect fetal development. There are a number of factors that can potentially explain disadvantaged women's greater susceptibility. These include that disadvantaged women are more likely to

\footnotetext{
${ }^{5}$ But not all the steps were filled in for any one country, save Sweden, where the paper by Mood et al. (2012) covers all the steps in the life course. In the larger study, most outcomes were measured for only one cohort. For more, see Ermisch et al. (2012), especially Chap. 2.

${ }^{6}$ In this review we draw heavily on recent reviews of the child development literature by Aizer and Currie 2014; Magnuson and Duncan 2014; Heckman and Mosso 2014; Duncan and Magnuson 2013.
} 
live in crowded homes, are more reliant on public transportation, are less able to stay home from work when ill, are less likely to be immunized, and are less likely to believe the influenza vaccine to be effective (Wooten et al. 2012; Sanders 2012; Quinn et al. 2011). Finally, women who are poor, minority, or both are also more likely to be the victims of domestic violence (Vest et al. 2002). The literature on maternal health, exposure to toxins and the like, and poverty strongly suggest that from conception through birth, children from lower-income families are at a disadvantage in comparison to those born to higher-income families.

Moreover, there is evidence that poor birth outcomes and low birth weight have effects that are liable to persist through childhood and even into adulthood. In a recent paper, Figlio and colleagues (2014) find that the effects of poor neonatal health on adult outcomes are largely determined early in life and continue for all births to rich and poor families alike and to families at all levels of educational attainment (Figlio et al. 2014). However, children with poor neonatal health born to highly educated families perform much better in the longer run than do those with good neonatal health born to poorly educated families, suggesting that patterns of nurture and early child development can at least partially overcome poor health at birth. Their findings are very much in keeping with the literature on the positive relationship between household income and health status in childhood and adulthood (Hoynes et al. 2012; Dahl and Lochner 2012) and are consistent with the notion that parental inputs and neonatal health are complements rather than substitutes, a "dynamic complementarity" that we return to below.

Recent research has focused on understanding how environmental experiences, including stress and poverty, affect the underlying neurocognitive, biological, and physiological processes of development. This phenomenon is often referred to as the way that "poverty gets under the skin." About five years ago, early research identified abnormal levels of, and fluctuations in, cortisol (the "stress" hormone) as the primary underlying mechanism (McEwen and Gianaros 2010; Champagne and Mashoodh 2009; Seeman et al. 2010). More recently, given that stress-related, elevated levels of cortisol in the mother can affect the placenta, researchers have focused on the potential negative effects of maternal stress on fetal outcomes. Comparisons of siblings suggest that those who were apparently exposed to higherthan-average levels of cortisol in utero have lower IQ levels at age 7 and complete one less year of schooling (Aizer et al. 2012). In some recent studies, environmental experiences are linked to individual differences in developmental outcomes through stable and permanent changes in genetic expressions (Essex et al. 2013).

Although genetic endowments are largely invariant during development, there is considerable change in the epigenome- the biochemical system that regulates gene expression. Moreover, the epigenome has been found to be particularly responsive to environmental conditions, including poverty directly (Hanson et al. 2013; Essex et al. 2013; Boyce 2012; Sameroff 2010). Research has also found that early maternal stressors are related to epigenetic changes in their children during adolescence, with implications for their mental health (Hanson et al. 2014; Knudsen et al. 2006; Shonkoff et al. 2012). Finally in a recent study of great importance, Noble et al. (2015) provide the strongest evidence to date that socioeconomic disparities, 
particularly in income, are associated with large differences in cognitive development. Investigating patterns in brain structure across social and economic status, they found that children from lower-income families had relatively large differences in brain surface area in comparison to children from higher-income families, likely predictive of future differences in cognitive development.

Postpartum health and development (but prior to pre-preschool) is also important for child outcomes (Beller 2009). Several studies have documented the relationship between the amount and type of speech directed at a child by caregivers during the course of a typical day and the child's later expressive language and vocabulary (Weisleder and Fernald 2013; Rowe 2012). Studies of parenting and children's selfregulation also point to associations between parents' early support of their children's autonomy with later assessments of children's executive function (Landry et al. 2006; Bernier et al. 2010). Because higher-income parents are typically better educated and also have more money to invest, their children tend to have better outcomes than children of lower-income parents (Guryan et al. 2008; Yeung et al. 2002; Kaushal et al. 2011). Further, child-parent interactions, such as those outlined above, may be more productive for children born healthier. In other words, prenatal and postpartum investments may be complementary in producing better child outcomes (Bono et al. 2012; Hsin 2012).

In fact, research on the malleability of cognitive and language abilities shows these skills to be highly responsive to both positive and negative influences (Fox et al. 2010; Shonkoff 2010). In effect this suggests that newborn health and postnatal investments are complementary. This hypothesis, termed "dynamic complementarity," implies that the impacts of general parental investments, as well as early childhood education on child outcomes, will be greater for children who enter the preschool period with higher levels of cognitive and socioemotional skills (Aizer and Cunha 2012). In particular, preschool settings that are designed to expose children to sensitive caregiving environments should increase children's socioemotional skills much more among children with more sensitive caregivers in their home environments (Duncan 2014). This process of dynamic complementarity is still just a hypothesis, and one whose negative effects can be overcome by consistent, strong investments in children from the beginning of their lives, even for the most disadvantaged children (Cunha and Heckman 2007, 2008; Camilli et al. 2010; Heckman and Mosso 2014).

Thus, despite some uncertainty, the available evidence suggests that the consequences of initial health disadvantages associated with being born to a poor mother are likely to be exacerbated over time without intensive policy and practice interventions. Unfortunately, children with poorer initial health endowments typically receive fewer postnatal investments, and the investments they do receive may be less effective due to dynamic complementarity. This mechanism can explain not only the considerable persistence of in-utero conditions in later-life outcomes, but also why the long-term impact of low birth weight is greater when children are born into poverty and other unsatisfactory circumstances (Figlio et al. 2014). In terms of the framework of this project, early gaps can easily become larger and increasingly 
more difficult to reduce. However, continuous investments before the preschool period can still make an important difference in outcomes.

\section{Preschool Investments}

The life-cycle model leads us to the topic of preschool and its effectiveness. Although about $70 \%$ of children overall have attended a preschool-like program, the rate is much higher among the top two quintiles of the income distribution (nearly $90 \%$ ) than among the three bottom-income quintiles (65\%) (Duncan and Magnuson 2013; Magnuson et al. 2012). Currently, about $25 \%$ of children do not attend preschool at all before they enter kindergarten, while some unknown fraction of children are privately reared in strong developmental childcare and early education systems from ages 1 or 2 . Because lower-income children are least likely to be enrolled compared to higher-income children, and because income gaps in early development forecast lower levels of human capital accumulation, improving enrollment and attendance for low-income children should be a first priority for policy. ${ }^{7}$ But in this area, the United States pales in comparison to other nations. According to the Organisation for Economic Co-operation and Development (OECD 2015, chart PF3.1.A) public expenditure on childcare and early education services was less than $0.5 \%$ of GDP in 2011, placing the U.S. last among rich OECD countries in such efforts. Surprisingly, African-American children are, if anything, more likely than comparable White children to be enrolled in school- or center-based care at age 5, though often of lesser quality (Magnuson et al. 2006; Magnuson and Waldfogel 2005).

Any discussion about preschool for disadvantaged children must begin with the much maligned, but currently irreplaceable, Head Start program, the oldest and largest federally funded preschool program in the United States. Head Start not only provides early childhood education, care, and services for children but also tries to promote parental success. Although recent critical federal evaluations suggest that the effects of Head Start on learning and cognitive outcomes begin to fade in the second grade and later disappear, others defend the program as having positive longer-term outcomes for children and parents (Duncan and Magnuson 2011).

For instance, employing a quasi-experimental design, Sabol and Chase-Lansdale (2015) examined whether children's participation in Head Start promoted parents' educational advancement and employment. They found that parents of 3-year-old Head Start children had steep increases in their own educational attainment by the time the child was 6 , with strong effects particularly for African-American parents.

\footnotetext{
${ }^{7}$ We also note that there are other demographic groups that have comparatively low levels of preschool enrollment-Hispanic children and children of immigrants. No doubt, part, but not all, of the lower rates of enrollment can be attributed to their families having lower incomes. But both language barriers and cultural factors are also likely influences that play a role in the lower levels of enrollment among Hispanic children and children of immigrants (Takanishi 2004).
} 
Further, Head Start centers offering full-day service boost cognitive skills more than other centers, while Head Start centers offering frequent home visits are especially effective at raising noncognitive skills in children and adults (Cunha and Heckman 2008; Cunha et al. 2010; Walters 2014). Carneiro and Ginja (2014) provide new estimates of long-term impacts of Head Start on health and behavioral problems, suggesting that participation in the program reduces the incidence of behavioral problems, health problems, and obesity of male children as teens, lowers depression and obesity among adolescents, and reduces engagement in criminal activities and idleness for young adults.

What skill development strategies will likely have the greatest payoff in preschools? Heckman and colleagues ${ }^{8}$ have continued to establish that we need to better understand the mechanisms through which successful early childhood programs work. And their evidence suggests those that appear to work best affect the so-called "soft skills," social and behavioral outcomes such as character building, self-control, and conscientiousness, in comparison to cognitive skills which often fade out early in elementary school (Heckman 2012; Kautz et al. 2014). For instance, those young children and their parents who practice small acts of self-control find it easier to perform big acts in times of crisis. Quality preschools and parenting coaches have produced lasting effects by encouraging young parents and students to observe basic etiquette and practice small but regular acts of self-restraint (Roberts et al. 2014).

Simple things like showing up also matter. Research from the Consortium on Chicago School Research at the University of Chicago suggests almost half of 3 -year-olds and more than a third of 4-year-olds enrolled in pre-K are "chronically absent"- defined as missing more than $10 \%$ of days-from Chicago's pre-K program and, further, these absences are strongly correlated with negative outcomes in elementary school learning (Ehrlich et al. 2013). Such findings reinforce the connection between health and learning and, in particular, the dynamic complementarity of bad health and poor early childhood education outcomes as the child transfers from preschool to elementary school.

The most encouraging news is that there are successful models of preschool on which to build. One example of a public preschool program that has developed exemplary curricula by integrating proven literacy, math, and social skills interventions and then implemented them, is the Boston Pre-Kindergarten Program (Duncan and Murnane 2013). Rigorous evaluation reveals large impacts on vocabulary, math, and reading but smaller impacts on executive function (Duncan and Murnane 2013; Weiland and Yoshikawa 2013). Another is Chicago's Child Parent Center education program. This program engages not only with the children but also with their parents to foster better learning at home and to help families address the myriad challenges they face. The program comprises a dedicated parent resource teacher and a school community representative who engage parents both inside and outside the program. Students who participate in the program are better prepared for kindergarten, perform better on standardized tests, are less likely to need special education

${ }^{8}$ Heckman et al. 2013; Heckman and Mosso 2014; Heckman and Kautz 2014; Kautz et al. 2014. 
services, and are more likely to graduate from high school and be successful in life (Chetty et al. 2011). The program is now funded in the Chicago area by a series of Social Impact Bonds, where the public sector pays back private investments in outcomes that reduce future public costs (Costa 2014).

In summary, we are finally coming to understand the importance of maternal and child health, as well as maternal behaviors related to poverty, substance abuse, bad neighborhoods, stress, pollution, and domestic violence. Together these toxic ingredients make a powerful negative cocktail of dynamic complementarity that is hard to overcome without strong and continuous interventions as a child moves from birth through preschool. Further study and examination of evidence on child outcomes are beginning to tell us not only what conditions matter, but also what treatments appear to offer effective counterweights. To reduce disparities in opportunity, we must take advantage of these findings.

\section{The Five Factors That Determine Early Development}

Here we briefly review five separate, but often highly intercorrelated, factors or forces that influence child development and, ultimately, IGM by determining whether the gates to opportunities are open, slightly ajar, or closed for the child. Unless we are able to counter the distributions of advantage and disadvantage that are influenced by each of these factors, we will not be able to meaningfully increase opportunity or mobility for those children born to disadvantage. We begin with the two most closely related factors: family structure early in life and parenting. These are followed by economic factors (money), social institutions, and neighborhoods.

\section{Family Structure}

Family formation and parenting practice are treated together, as they are often highly intertwined and because they matter a great deal from a child's earliest days through adolescence and beyond. Many analysts believe that family composition and stability may matter even more than income for equality of opportunity and IGM. As McLanahan and coauthors (McLanahan 2014; McLanahan and Jacobsen 2013) and Cherlin (2014) have established, we are seeing a growing parental class divide in America - in income, education, neighborhood, and especially family formation.

Children born into continuously married families have much higher economic mobility than those in single-parent families, especially those headed by unmarried mothers. In this regard, we must recognize the long, steady decline of marriage. In 1960 , only $12 \%$ of adults aged 25-34 had never married; by the time they were 45 to 54 , the never-married share had dropped to $5 \%$. But by $2010,47 \%$ of Americans 25-34 had never married, and based on present trends, their share will be about 
$25 \%$ in 2030 when they're 45-54 (Wang and Parker 2014). This is a stunning decline that befuddles demographers and social policy wonks alike. The growth in the number of single unmarried mothers in the United States has both been massive and concentrated among the least educated (no high school degree), as well as those, especially in their 20s, who have graduated high school and even may have some postsecondary education. These women are typically more educated than the men who fathered their children and do not want to marry men who do not have an education or regular jobs. Some scholars believe that changes in the labor market have been particularly important in reducing the marriageability of undereducated men (Wilson 1996). Others argue that incarceration and street violence have drastically reduced the numbers of Black men who are eligible for marriage. ${ }^{9}$

Because family differences begin at birth, it is often useful to characterize the middle ground of an issue by looking at the extremes. If we examine both what is considered to be the best and the worst ways to become a parent, we can better understand the genesis of "diverging destinies" (McLanahan 2014; McLanahan and Jacobsen 2013). The "best" way to become a parent is through living the American Dream. The process is the same for men and women alike: Finish school, find a decent job, find a partner you can rely on, make plans for a future together including marriage as a commitment device (see Lundberg and Pollak 2013), and then have a baby. Following this path will likely mean that parents are age 25 or older, more educated, and more likely to have a stable marriage. They have better parenting skills and smaller families, along with more income, auxiliary benefits, and assets to support their children. For their children, these characteristics translate into open gates for opportunity.

At the other extreme, the step "have a baby" (between the ages of 16 and 22) moves to the top of the list, preceding all the other steps. These parents typically have not finished school, do not have a steady or well-paying job, do not have a stable marriage or steady partnership, and likely never had a plan. They have less education (high school or less), are younger and less skilled, and have lower wages and fewer benefits and more multipartner fertility. The result of this personal choice is less social and economic stability, as well as fewer resources and opportunities for their children (Smeeding et al. 2011b; Carlson and Meyer 2014; Smeeding 2015). For single women under 30, almost $70 \%$ of pregnancies are also unintended (Sawhill 2014). And there is now strong evidence that unintended pregnancies produce poorer outcomes in children (Ibid.).

Changes in fertility/marriage, cohabitation/divorce, maternal employment, and maternal education are therefore reinforcing differences in income inequality (see below) and further reducing IGM among children. Perhaps the relationship between children and their mothers is the most important mechanism of how families affect development. Better educated women are more likely to obtain jobs with higher earnings and family leave benefits, allowing these mothers to invest more time and

\footnotetext{
${ }^{9}$ Justin Wolfers, David Leonhardt, and Kevin Quealy. "1.5 Million Missing Black Men,” New York Times, April 20, 2015, http://www.nytimes.com/interactive/2015/04/20/upshot/missing-blackmen.html?abt=0002\&abg=0
} 
money in their children. They are also more likely to have fewer children, and children born later in life. Mother's age at childbirth matters because it is a strong indicator of the child's future economic mobility.

\section{Parenting}

The quality of parenting is also highly unequal because of differences in parental endowments with respect to skills (type and amount) and economic resources (income and wealth). Hours spent reading to a young child or talking with a young child make a big difference in later outcomes. Soft skills such as conflict resolution or how to respond to setbacks are also usually better taught by those who have those skills-typically those with more education. And, of course, parental educational attainment is highly correlated with childhood education; high-skill parents not only realize the value of education but also make every effort to make sure their children succeed in reaching a high level of educational attainment.

Top-quintile spending on children's' enrichment (special classes, music, camps, and other experiences) is now almost $\$ 8900$ per year, three times that of low-income quintile parents, who spend about $\$ 1320$ on the same goods and services (Kaushal et al. 2011). These differences, confirmed in multiple studies, suggest that long before preschool, children born to highly educated and stable families acquire strong foundations in both cognitive and behavioral skills. ${ }^{10}$ Using a composite measure of parenting quality, ${ }^{11}$ researchers have established that the children of parents in the lowest quartile (lowest one-fourth) do worse on multiple outcomes at every stage of the life cycle in comparison to those born to the highest-quartile parents, with differences in success rates on the order of 30-45\% at each stage.

\section{Economic Inequality: Money Matters-A Lot}

There is a range of opinions about general trends in IGM, the trends in top-decile and bottom-decile income mobility, and the complicated relationship between income/wealth inequality and IGM. Nonetheless, almost all researchers agree that because differences in parental incomes between the top and bottom quintiles have grown substantially, the stakes for remaining at the bottom or the top of the distribution are now much larger, even with constant mobility parameters, because the rungs of the income ladder are much further apart. Figure 8.2 uses the Congressional Budget Office (2011) estimates of after-tax and transfer incomes for families with

\footnotetext{
${ }^{10}$ Readers should consult Kalil et al. 2012; Philips 2011.

${ }^{11}$ The Reeves and Howard (2013) parenting scale is based on Children of the National Longitudinal Survey of Youth "HOME" assessments at various life stages, which includes pictures, observation, interviews, etc., as well as information about literacy activities.
} 


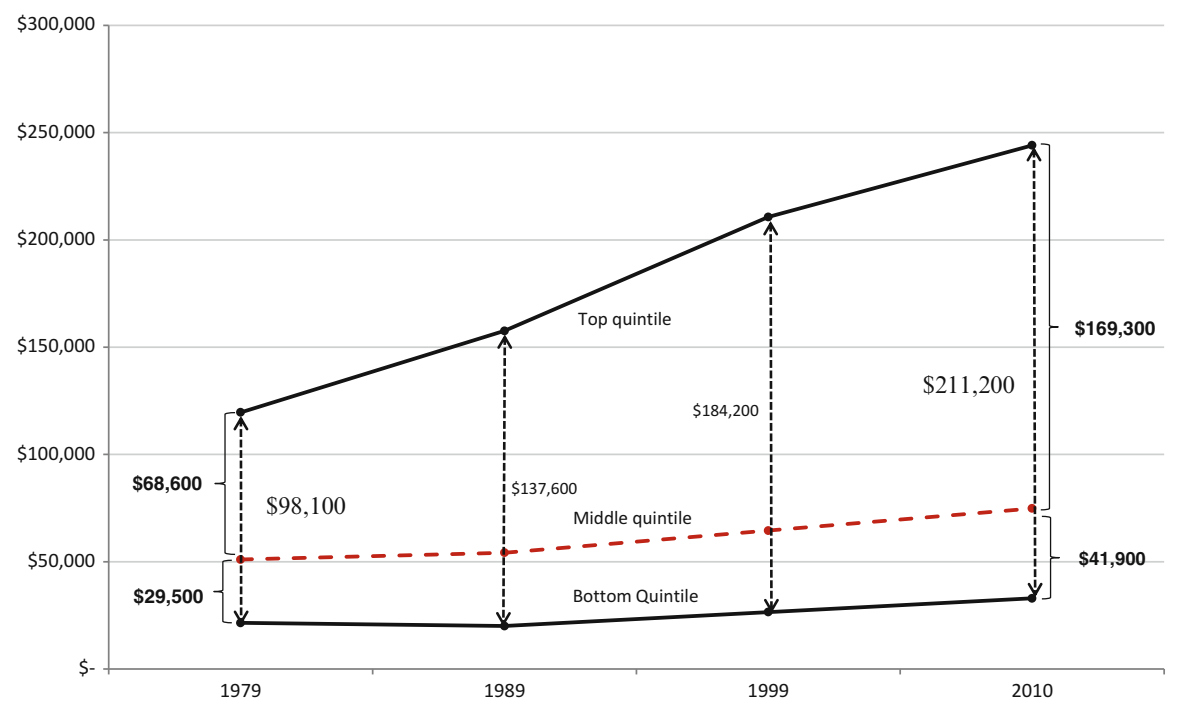

Fig. 8.2 After-tax and transfer disposable income for households with children: mean income in bottom, middle, and top quintiles, 1979-2010 (Source: Congressional Budget Office, http://www. cbo.gov/sites/default/files/cbofiles/attachments/44604-AverageTaxRates_Supplemental.xlsx)

children to show that the family income gap rose by almost $\$ 113,000$, or $115 \%$, from 1979-2010. ${ }^{12}$ This is a huge change across a fairly short time span.

This figure raises an important question: Should we be more concerned about relative or absolute mobility? The former refers to how children rank in terms of an outcome variable such as income relative to their parents' rank; the latter refers to the level of income that a child achieves and whether it is higher or lower than their parents' incomes (see Chap. 13). For example, do we care about absolute class gap or relative class gaps in child outcomes? In Fig. 8.2, both the top- and bottomquintile children are better off in income terms in 2010 than in 1979, but the gap between them has widened. However, fully half of the gain in real incomes in the bottom $20^{\text {th }}$ percentile is because of the increase in the cost of insured health care, which is assigned to the poor as income. Of course, the cost of health care insurance rises for the other quintiles, too, but is a much smaller fraction of their incomes and income gains (CBO 2011), hence overstating the income gains to the poor.

\footnotetext{
${ }^{12}$ Because of the growth in the very top income shares, how much is it driven by the top $1 \%$ in any given year? If we use the mean of other percentiles to gauge the change at the top, then how much smaller or bigger are the differences between top and bottom? The gap between the bottom and the top, where the top is the 81 st -90 th, grows $\$ 48,900$, or $49.9 \%$, over this period; the gap using the 91 st -95 th percentile as the top grows $\$ 68,800$, or $70.1 \%$. And if the top is the 96th-99th percentile, the gap grows $\$ 115,000$, or $117.2 \%$.
} 
Further, Fig. 8.2 shows that middle class children ${ }^{13}$ are losing more ground relative to top-end children than are those at the bottom relative to the middle. The topto-middle gap has expanded from $\$ 68,600$ to $\$ 169,300$, or by over $\$ 100,000$, from $1979-2010$, while the middle-to-bottom gap rose from $\$ 29,500$ to $\$ 41,900$, or by about $\$ 12,400$, over this same period. ${ }^{14}$ It therefore appears that the top-end children are leaving the middle (and everyone else!) behind and helps explain why most "middle class" Americans worry about their children's future socioeconomic status, and why we see consistent calls for inclusive prosperity and shared growth (Summers and Balls 2015).

In a world where wages for most education groups are flat, as David Autor's (2014; Fig. 8.2) recent review of full-time workers makes clear, one finds that incomes and wages are stagnant or worse for undereducated men, not to mention relatively flat wages over the past decade even for men who are college graduates. This phenomenon also emerges for women since 2007 (Fig. 8.3). Even if women's wages at the bachelor's degree level have flattened since the Great Recession, women's rising wages over the longer term are in contrast to men's, except for the most educated men with post-bachelor's degrees. Beyond the diverging patterns of individual wages, the increase in assortative mating - whereby members of the same social and economic class are more likely to marry each other-substantially compounds income differences across families. ${ }^{15}$ Evidently, these "mated" high-skill parents are at a substantial advantage in comparison to lower-income men or women who fail to marry or partner and have only a single income to support their families.

If anything, the Great Recession likely has made differences in wages and incomes much worse, as we see increasingly widespread differences in employment and wages by education and age, with income gains mainly above the bachelor's degree level, where the IGM correlation of parents and kids' education is highest (Fig. 8.3; Torche 2011). Cross-national research suggests that the premiums in pay for the highest educated are the largest in the U.S., meaning that the minority who attain a bachelor's degree and beyond do most well in the U.S. labor market compared to their lesser educated counterparts (Autor 2014; Blanden et al. 2014; Ermisch et al. 2012). Much of this difference comes from the lack of progress in educational attainment in the United States compared to other rich nations (OECD 2014).

\footnotetext{
${ }^{13}$ Middle class children are those in households with the mean income of middle-quintile families with children.

${ }^{14}$ Again, the reader must be careful as most of the gains in the lowest income class over this period-just about half — can be attributed to including the value of Medicaid and the State Children's Health Insurance Program in the incomes of households with children, where the value of Medicaid is far above the willingness of these households to pay for it.

${ }^{15}$ One can perform this operation by combining the incomes of men and women at each education level in Figure 8.3, producing a perfectly assortatively mated outcome by educational attainment that looks much like Figure 8.2. McCall and Burke (2014) show that the combined earnings rankings of husbands and wives at the upper end is actually a total sum of 160-170 (where husbands and wives are ranked by earnings quintiles from 10 to 100 ).
} 
a

Real weekly earnings relative to 1963 (men)

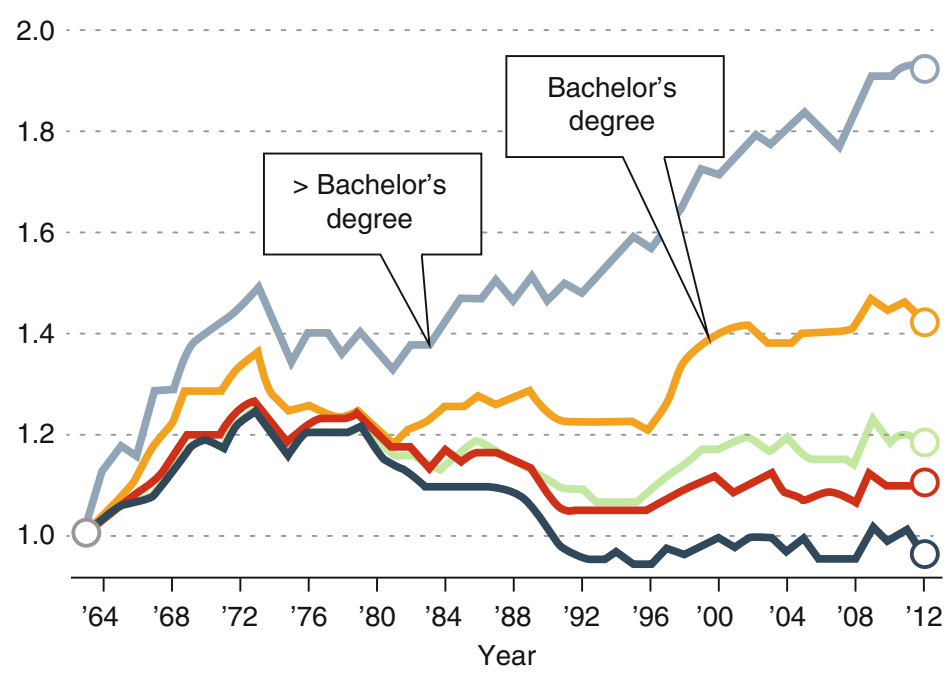

b

Real weekly earnings relative to 1963 (women)

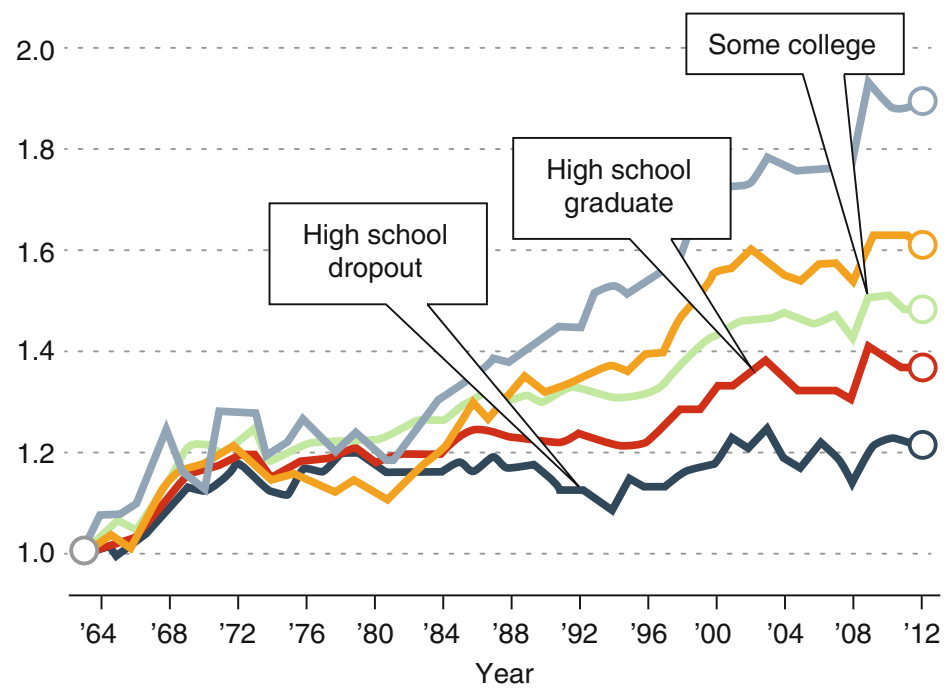

Fig. 8.3 Changes in real wage levels of full-time U.S. workers by sex and education, 1963-2012 (Reproduced from Autor 2014)

Of course, both earned incomes matter for all two-parent families. For families with children under 14, the United States has by far the largest number of twoparent full-time workers among the rich OECD countries. Nearly $60 \%$ of children under 14 living in coupled households have both parents working full time in the 
U.S., far more than in most other nations. For instance, German and Dutch couples with dual full-time earners represent less than $20 \%$ of all two-parent working households. ${ }^{16}$ But because of the Great Recession and the high rates of long-term unemployment that are still present, along with the disappearance of middle-wage jobs, maintaining steady full-time work is often difficult (Kenworthy and Smeeding 2014). Also, changes in housing markets and plant closings have led to a situation where, if one parent loses his or her job, the family is not able to move to another location due to the risk of selling their home at a loss or giving up the one remaining job that they have. In fact, the growth of low-wage service jobs since the Great Recession fits well with the U.S. having by far the largest number of workers who work weekends and evenings (Hamermesh and Stancanelli 2014). There is also evidence that median incomes rose from 1979, and especially from 2000 to 2007, in the United States due almost exclusively to added hours of work and not higher wages (Mishel 2013). These work patterns pose both economic and time costs on all parents who are also raising children, especially on single parents.

Although money matters, as we have established above, it is not just about income. Consumption and wealth also matter (Fisher et al. 2015). When one looks at the placement of children across the consumption and wealth distributions, we find that they are located in very different parts of the distribution compared to the positions of elders and childless adults. Children are overrepresented in the bottom half of all of these distributions, leading to concerns about their upward mobility, certainly in comparison to the minority of advantaged children who are located at the top of the wealth and consumption scales.

None of the current analyses of inequality or IGM have captured the full effect of net worth (assets, debt, and wealth) on consumption or income by considering all three measures of well-being simultaneously for the same households-although we know that each gives a different and important perspective on the distribution of economic well-being, and, most likely, a different outcome when considering the effects of inequality on IGM (Pfeffer 2011). For instance, recent work by Pfeffer and Hällsten (2012) and the Federal Reserve's Survey of Consumer Finances (SCF) (Yellen 2014) show that since 2001 (with wealth measured in early 2013), wealth inequality had increased and income inequality with it, especially at the top. And overall financial wealth has increased by $20 \%$ since the time of both surveys, mainly to the benefit of those with the highest wealth levels. In particular, Pfeffer and Hällsten (2012) establish that the impact of parental wealth on children partly operates through its insurance-like effects for children (i.e., a "private family safety net"). Higher wealth creates the ability to purchase higher-quality childcare (e.g., a nanny), to afford higher-priced homes for better quality local preschools, or to pay

\footnotetext{
${ }^{16}$ OECD Family Policy Database 2014. Chart LMF1.1.A "Children in couple households by parental employment status, 2011," http://www.oecd.org/els/family/LMF_1_1_Children_in_families_by_employment_status_Jul2014.pdf
} 
for tuition for private preschools. ${ }^{17}$ Reeves (2013) and Smeeding (2014) refer to this as the "glass floor" effect, and it makes a difference from childbirth onward.

\section{Social Institutions}

In the United States, as in other rich nations, we are aware of a set of social institutions and social policies that are intended to ameliorate some of the differences in opportunity that come from differences in private incomes and wealth. The two most important are health care and public education (in the present case, highquality preschools). ${ }^{18}$ The major social institution that almost all children experience from conception through preschool is the health care system, especially the pediatricians and other health professionals who are a part of that system. The U.S. health care system does not yet provide high-quality care to all of its poor and middle class children. The availability of such care is especially important for children who are born with chronic exposure to toxins (e.g., lead), as well as parental smoking, alcohol, and substance abuse. Hence the children who would most benefit from high-quality, chronic-illness-oriented health care are the ones least likely to be receiving it. The passage and start of the Affordable Care Act may in time make a difference in patterns and continuity of care, but much can be done to improve it.

The second institution is the school system, including both subsidized and publicly provided early childhood education. The interaction between parental and child education has been studied at least back through Becker and Tomes (1979, 1986). Tests of their model by others (e.g., Solon 2014) have established that intergenerational correlations in socioeconomic status (or IGM) in later life can arise from the greater knowledge and financial ability of better-off parents to invest in their children's human capital, from children's genetic or cultural inheritance, or a combination of all. ${ }^{19}$ Hence, in the opinions of many analysts, the schooling system, including preschool, often serves to reinforce existing patterns in IGM that are the consequence of differences in parenting, family stability, and parental education, as well as economic differences (Reardon 2011). ${ }^{20}$

\footnotetext{
${ }^{17}$ These differences also work well later in life to finance 529 college savings plans and pre-fund college with tax-free interest and capital gains, as well as the greater ability to do more for welltimed inter-vivos transfers, especially for the following generations. See Kirkegaard 2015; Fisher et al. 2015.

${ }^{18}$ For poor children, one might add the legal and child protective service system, the child support system, and the childhood disability systems, but they are beyond the scope of this chapter.

${ }^{19}$ Because these different sources of intergenerational status transmission produce similar empirical results, distinguishing the processes from one another is therefore a difficult task. But new research by Seshadri et al. (2014) presents a model of human capital accumulation that isolates the direct effect of parents' human capital on children's human capital and finds substantial evidence of strong parental spillover effect on children's educational attainment.

${ }^{20}$ Also Sean F. Reardon, "No Rich Child Left Behind," The Great Divide, New York Times, April 27, 2013, http://opinionator.blogs.nytimes.com/2013/04/27/no-rich-child-left-behind/
} 
Finally, the methods by which health care and schooling are supported by public policy in the United States differ substantially from those in other developed nations. Instead of direct and universal open access to health care and preschool, we regressively subsidize these and other goods such as housing in good neighborhoods and college expenses using income tax subsidies that benefit the rich far more than the poor (Kirkegaard 2015).

\section{Neighborhoods and the Role of Place}

Neighborhoods and residential contexts clearly affect prospects for IGM. Previous research by Sharkey (2013) and others suggests that economic segregation can at least in part explain IGM patterns. School quality, exposure to community violence, elements in the physical environment (air pollution, noise, lead), and long-term exposure to neighborhood disadvantage can and do affect academic trajectories, child cognitive development, and later economic outcomes as seen above (Aizer and Currie 2014). For those living in a high-poverty neighborhood, the odds of falling down the income ladder as adults - being worse off than their parents-are $50 \%$ on average, even for those children who have not grown up in a poor family. In other words, neighborhoods matter in terms of schooling and other attributes; structural clustering of disadvantages contributes to these factors reinforcing each other to produce bad outcomes, above and beyond the contributions of individual families' characteristics. In fact, a recent study by Chetty and Hendren (2015) concludes that "neighborhood effects are substantial, especially for children in lowincome families. The county in which a child grows up explains nearly half as much of the variation in his/her earnings as his/her parents' incomes."

Declining manufacturing sector employment in inner cities, accompanied by the outmigration of Whites and the rising Black middle class in the 1990s and 2000s, left behind pockets of concentrated disadvantage (Wilson 1987, 1996; see also Chap. 2). From 1980 to 2010, economic segregation by neighborhood grew, while racial segregation per se changed by little. These poor and still racially segregated neighborhoods are characterized not just by high rates of poverty and crime, but also by high rates of unemployment, single parenthood, and multiple-partner fertility (Kneebone 2014). And while these neighborhoods were heavily populated by Blacks in the '80s and '90s, Murray (2012) shows similar patterns in formerly White middle class neighborhoods as well. Of course there are good urban neighborhoods, with clean parks and play spaces, new schools and childcare centers, readily available high-quality health care, and little crime. But these are largely occupied by well-to-do parents who pay housing and property tax prices to segregate themselves and their families (Brodmann and Massey 2014; Kirkegaard 2015). 


\section{The Changing Race and Ethnicity of American Children}

There are stark differences in mobility rates for different racial groups, especially between Whites and African-Americans. Half the Black children growing up in families in the lowest income quintile remain stuck there as adults (51\%), compared to just one in four Whites (23\%) (Smeeding 2015). Mobility is also lower for Hispanic children than White children. Research on differences in mobility between Blacks and Whites reveal stark differences: On average, Blacks experience less upward mobility and Whites experience less downward mobility. In fact, Whites are on average 20-30 percentage points more likely to experience upward mobility than are Blacks. Mazumder (2014) finds that Black men raised in middle class families are 17 percentage points more likely to be downwardly mobile than are White men raised in the middle (38\% of Black men fall out, compared with $21 \%$ of White men). A range of personal and background characteristics - such as parental occupational status, individual educational attainment, family wealth, and marital status_-all help explain this gap.

We know far less about the mobility of ethnic minorities, especially immigrants, because they are not part of older panel datasets. For instance, the Panel Study of Income Dynamics and various National Longitudinal Surveys help assess IGM but are constrained by study and sample designs that began with the original adult samples in the 1960s or 1970s and followed their children, hence excluding all immigrant groups who have not "married into" the dataset, especially the large recent immigrant cohorts that are not captured at all (Duncan and Trejo 2015). What we know about Hispanic IGM, for instance, is sparse and, again, includes only those who emigrated before the recent immigration boom (see Duncan and Trejo 2015; Acs 2011). For instance, there is limited data about economic mobility among Hispanic families, who tend to have lower incomes compared to non-Hispanic Blacks and Whites but more stable family structures than do Blacks. ${ }^{21}$

Most importantly, perhaps, the racial and ethnic makeup of today's children is changing rapidly (Frey 2014). In 2011, for the first time, less than half of the children born in America were to two White Anglo-American partners. Soon most children will be minority children, including White Anglo children. By 2050, Anglo-Americans will be less than half of the population (compared to aging baby boomers, the vast majority of whom are White Anglo-American). Hispanics, Asians, and multiracial populations are expected to double in size over the next 40 years as the result of immigration, higher birth rates among minority populations already here, and more interracial marriages. While these changes will challenge the nation's legal, political, and economic systems, they are already beginning to affect the youngest of the emerging majority who are just now entering our school systems. Indeed one should not forget that the children whose mobility we are trying to improve early on are not likely to be White and Anglo-Saxon by heritage

\footnotetext{
${ }^{21}$ One more promising approach is for future studies to begin with the current population and trace back to find their parental heritage instead of the other way around (Grusky et al. 2015).
} 
(Frey 2014). In succeeding decades, the combination of this explosion with the diminishing numbers of the White Anglo baby boomers will produce intergenerational competition over governmental resources (see Brownstein and Taylor 2014).

\section{Using the Gates-Gaps Metaphor to Examine Opportunity and Mobility Early in Life}

Having reviewed some of the evidence on the major economic, demographic, and social forces and factors that impede upward mobility for our youngest, most vulnerable children, we briefly return to the three life-cycle gates. Our goal is to examine the evidence regarding trends in the distributions of opportunity and of outcomes; that is, in comparison to earlier cohorts, have the distributions for very young children growing up in the twenty-first century become more dispersed (i.e., greater inequality) or more concentrated (i.e., lesser inequality)?

Remember that gates represent access (open gates) or obstacles (closed gates) to the opportunities to accumulate human capital and to have the possibility of upward mobility. We have divided the early life-cycle age span into three segments, with endpoints chosen to match critical transition points. Now we look at the gaps at each point to see if they are increasing, which would signal the cumulative widening of differences across children as they age. We pay attention here both to the gaps we find at each transition point and, where possible, the trends that may affect patterns in gaps for future generations.

\section{Transition 1: Prenatal and Family Birth Status}

The first step involves being born at a normal birth weight to a nonpoor, mature (partnered or, better, married) mother who has at least a high school diploma. While we know a little about trends in life quality at birth (Aizer and Currie 2014), we know from the diverging destinies literature mentioned above that $41 \%$ of U.S. births are out of wedlock (vs. $11 \%$ in 1970) and half of all births to women under 30 are out of wedlock (Hamilton et al. 2013). A majority of these births are unplanned as young adults "drift" into parenthood because of failed contraception or ambivalence about school and life goals (Sawhill 2014).

And for these parents, family complexity, defined here as having one or more children with someone who is not the birth parent of his or her earlier child, is greatest. Multiple-partner fertility leads to very unstable lives for children and adults, replete with communication and coordination issues across parents, complicated living arrangements, and much less available time for rearing of children (Carlson and Meyer 2014; Amato et al. 2014). 
The facts are that marriage rates have fallen for all types of parents in their 20s, especially for White parents who, in earlier cohorts, were much more likely to marry by age 30 (Murray 2012; Cherlin 2014). But, somewhat surprisingly, the marriage rates for college graduates have held almost constant, along with relatively low divorce rates, over the past 40 years. This bifurcation in family formation patterns is a large component of the "diverging destinies" that young children face today.

Although never-married motherhood is rising among all women, we see in Fig. 8.4 that the fraction of never-married mothers with children under 18 is more than $20 \%$ for those who did not graduate secondary school and $15 \%$ for high school graduates, as compared to $3 \%$ for those with a bachelor's degree or more. And these differences have been almost continually expanding over the past 40 years. Not only is out-of-wedlock childbearing highest among the least educated, but these births occur mainly to younger mothers, most of whom are poor or near poor, and most of whom have unstable living conditions in terms of both partners and living conditions (Edin et al. 2012; Tach 2015). Over their lifetimes, these mothers have more children per woman on average than the typical mother (Smeeding et al. 2011b). In contrast, well-educated parents have fewer children later (in marriage) under much better economic circumstances (McLanahan 2014; Sawhill 2014).

Looking at unmarried mothers by education group in Fig. 8.5, we can get at the differences in being raised by an unmarried parent. These figures suggest that outof-wedlock childrearing almost has not changed at all since 1980 for college-educated

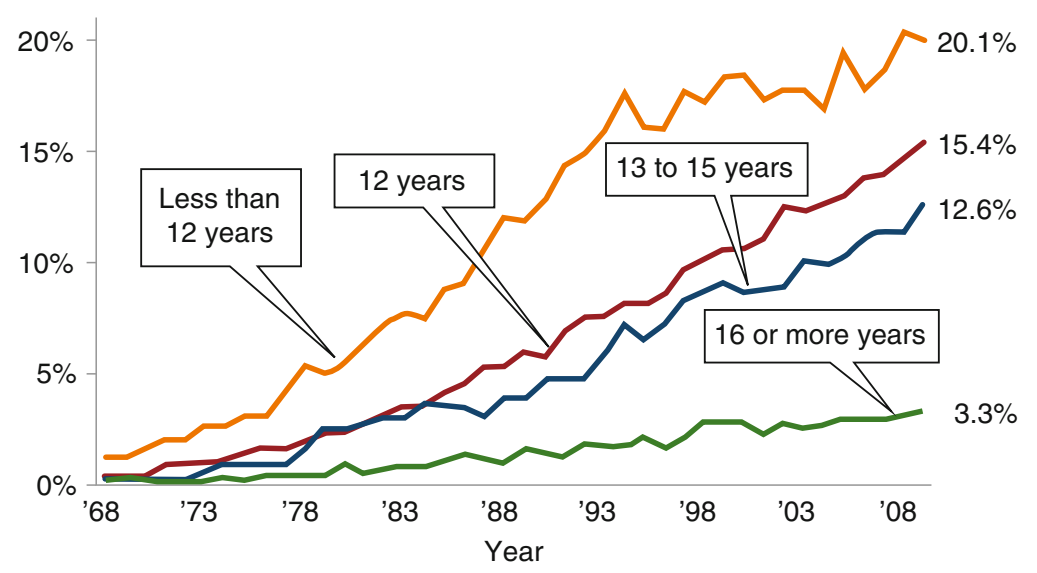

Fig. 8.4 Never-married mothers by education attainment (Source: Brookings tabulations of the Current Population Survey, Annual Social and Economic Supplement. Sawhill [2010], Fig. 10, 26; The Economics of Inequality, Poverty, and Discrimination in the 21 st century by Robert S. Rycroft. Reproduced with permission of Praeger in the format Republish in a book via Copyright Clearance Center. Notes: The sample includes noninstitutionalized, civilian women ages 16-64 with a child under age 18 living in their house. Never-married mothers are those who have never been married) 


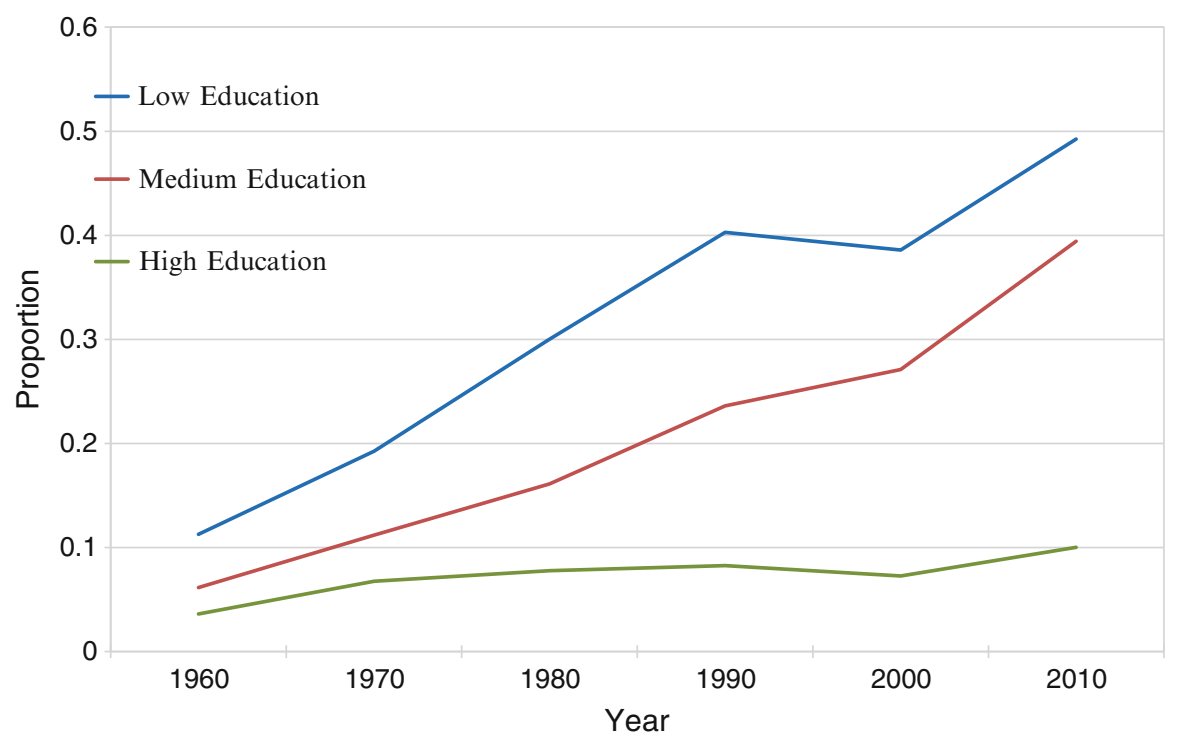

Fig. 8.5 Unmarried mothers by mothers' education (Source: IPUMS Census/ACS; Tach 2015)

(High Education) women, despite large increases among high school educated (Medium Education) and less educated (Low Education) women. These trends suggest widening differences and are not at all reassuring. ${ }^{22}$ To be sure, the choice to have an unplanned child early in life handicaps both the parent(s) and the child, reducing absolute and relative mobility for both (Smeeding 2015).

\section{Transition 2: Life at Early Ages, Post-Birth but before Preschool (6 Months to 3-4 Years)}

In the face of low levels of education, instability, and meager income, most young single parents, including cohabitating mothers, live stressful lives that are neither good for themselves nor for their children (Aizer and Currie 2014). Various studies document that time spent with young children in reading and personal interaction is much more developmentally oriented in older and more educated married-couple families than in younger single-unmarried-mother families. These differences are then mirrored by large differences in early language development (Kalil et al. 2012; Phillips 2011).

\footnotetext{
${ }^{22} \mathrm{Of}$ course one way to reduce this problem is reducing young unwanted pregnancy, which we turn to in the next section of the chapter.
} 
What is the evidence on the ways that developmental differences open up early in life? One important set of tests comparing children at 9 and 24 months of age was conducted by Halle et al. (2009) and nicely summarizes child development issues over this period. Halle et al. examined disparities in child outcomes at 9 and 24 months in 2008 using the Early Childhood Longitudinal Birth Cohort. They found that gaps in outcomes by race, ethnicity, parental income, and education were evident at 9 months and grew larger by 24 months. These gaps were evident across cognitive, social, behavioral, and health outcomes. Infants and toddlers from lowincome families scored lower on a cognitive assessment than infants and toddlers from higher-income families, were less likely to be in excellent or very good health at both 9 and 24 months, and were less likely to receive positive behavior ratings at 9 and 24 months.

Nearly half of all infants and toddlers-approximately 1.5 million children-in families with incomes below $200 \%$ of poverty at 9 and 24 months of age had multiple risk factors. The most prevalent risk factors were low family income and low maternal education at both 9 and 24 months (see Appendix). Equally important, given the demographic changes underway in the U.S., infants and toddlers from more at-risk backgrounds (i.e., children from racial/ethnic minority groups whose home language was not English, and/or who had mothers with low maternal education) scored lower on cognitive and positive behavior ratings (Fig. 8.6). In each of these minority groups, scores were below those for non-Hispanic White children and, in each case, differences were larger at 24 months than at 9 months.

When a child is getting ready to enter preschool, his or her first educational institution, several factors are important for whole child development, including the

\section{Bayley Cognitive Assessment}

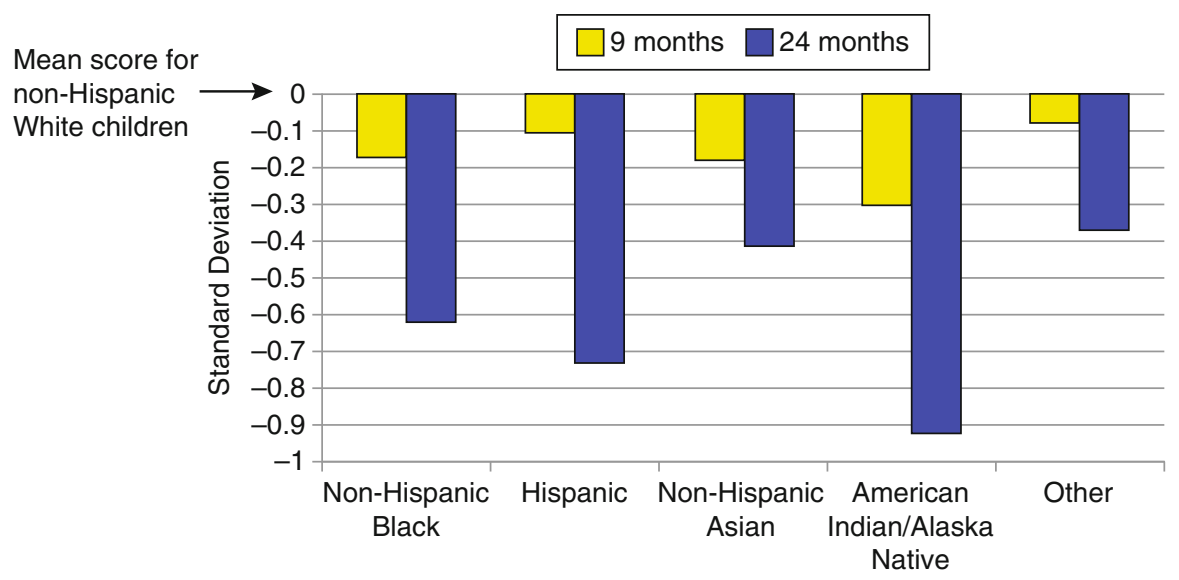

Fig. 8.6 Racial and ethnic cognitive disparities at ages 9 and 24 months (Source: Disparities in Early Learning and Development: Lessons from the Early Childhood Longitudinal Study - Birth Cohort (ECLS-B) - Executive Summary by Halle, Tamara, and Nicole Forry. Reproduced with permission of Child Trends Inc. in the format Republish in a book via Copyright Clearance Center) 
home environment, parental skills, and behaviors as reviewed above. With respect to health issues, parental mental health is liable to be a major barrier to well-child development, along with other barriers such as poor nutrition, vision problems, hearing deficits, undertreated asthma, anemia, and dental pain. These are all more common in low-income families, and are critical to readiness before the onset of formal care or schooling.

\section{Transition 3: Preschool and Early Childhood Education (Ages 4-6)}

The goal is to have children with pre-reading and foundational math skills and school-appropriate behavior by first grade. More specifically, the goals for all early childhood education programs, with parental inputs and reinforcement, are to create a "mobility mentality" consisting of a growth mindset (the belief that success is learned, not preordained), instilling confidence in children to succeed, and raising their aspirations, as well as those of their parents. They also need the grit and character development to see setbacks as hurdles to overcome, not impenetrable walls, and the persistence, if they confront a closed gate, to find ways to open it or discover other paths. Fostering these characteristics in children from disadvantaged backgrounds, along with instilling in parents the ability to take these lessons home with them and apply them, are crucial elements.

But the challenge is great. Only $38 \%$ of American 3-year-olds are enrolled in early childhood education programs (as compared to an average of $70 \%$ among the 34 richest OECD nations; OECD 2015). Moreover, U.S. children tend to enter early childhood education at age 4 . Even then, only $66 \%$ of 4-year-olds were enrolled in 2012 (the OECD average was $84 \%$ ), a slight decrease from $68 \%$ in 2005, when the OECD average was $79 \% .{ }^{23}$

It is well documented that there are large gaps in early childhood education and school readiness by parental education and income, which were most pronounced in the U.S. compared to other Anglo nations and which only recently have begun to stabilize (Bradbury et al. 2012). These gaps are larger now than in the past, in part because parents at the top spend vastly more in time and money on developmentally oriented goods and activities than those at the bottom (Kaushal et al. 2011; Kalil et al. 2012). We know that high-quality early childhood education programs are critical for development. Quality programs include productive teacher-child interactions, encouragement from teachers, and opportunities to engage with varied materials. Teacher quality and retention are also key ingredients for producing better outcomes for disadvantaged children. But these conditions are hard to establish or maintain in low-income areas (Duncan 2014).

\footnotetext{
${ }^{23}$ See OECD (2014) and figures in the section entitled "What Makes a Difference Early in Life?".
} 
President Obama's national drive to improve early childhood education for these children is central to the effort to overcome these gaps but is hampered by differential state take-up rates in expanding preschool to all children (Duncan and Magnuson 2011). Cross-national research in Denmark and France, where universal early childhood education is the norm, shows that effective high-quality preschools do reduce the slope of the relationship of achievement to family education background. But even so, the remaining differences in both cognitive and behavioral outcomes are still significant when outcomes are ranked by parental education (Bingley and Westergaard-Nielsen 2012; Dumas and Le Franc 2012). This suggests that while early childhood education can improve opportunity and mobility from the bottom, it is not by itself the "magic bullet" for achieving desirable levels of IGM.

\section{Cumulative Gaps?}

In many ways, the U.S. system of supports and institutions performs well enough to maintain but not reduce SES-related outcome gaps once school begins (Ermisch et al. 2012; Duncan and Magnuson 2013). Hence, the gap at the beginning of elementary school is key-assuming smaller gaps upon the start of grade school would in fact be maintained and not exacerbated. We do know from longitudinal studies that there are large gaps at 9 months that widen by 24 months. This is worrisome because cross-sectional studies reveal wide gaps based on pre-K assessments at ages 4-5 (see Bradbury et al. 2012). ${ }^{24}$ Thus, we need effective, scalable, and replicable interventions before preschool, as well as through the preschool period, if we are to make progress in improving mobility for children coming from disadvantaged backgrounds.

\section{Summary}

Essentially all the factors key to healthy child development are very much affected by parental circumstances at a point in time, and almost all the trends in differences in child development (or gaps) by parental incomes, education, and SES are on the upswing at early ages. Conditions at birth, family background, parenting, neighborhoods, social institutions, and economic circumstances all make it more difficult for low-income children, especially minority children, to successfully cross each transition point on their way to elementary school.

The social policy challenges are many, and are not just situated in the health and learning domains; the greater challenge is that medical and educational professionals

\footnotetext{
${ }^{24}$ Whereas the data we have on young children follows the same children from ages 9-24 months, we do not have follow-up data on the same children as they exit preschool or enter elementary school.
} 
must interact with social services and deal with fractured patterns of family life, in addition to the children themselves. Effective action requires the integration of policies across the health, education, and family assistance silos if we are to become more successful in boosting mobility from below.

\section{Policy Levers to Open Gates, Reduce Gaps, and Moderate Cumulative Gaps Early On}

America is finally beginning to awaken to the reality that the next generation is at risk. ${ }^{25}$ But we need to pay more than lip service to make a difference in children's chances for upward mobility. Moreover these challenges confront federal, state, and local authorities, as well as faith-based organizations, nongovernmental organizations, and even some organizations in the for-profit sector. In this final section we focus on some emerging green shoots of hope that need to be nurtured if we are to make progress in opening more opportunity gates and closing the gaps that emerge along the developmental trajectory. We begin with the prevention of unwanted pregnancies and children who begin life with a parent who is not yet prepared. We then move onto other policies that can make a difference in the lives of young children.

\section{Unwanted Pregnancy at Young Ages: An Agency Problem}

Despite the somewhat gloomy data cited above, the U.S. is making some progress in improving children's life chances through the reduction in the numbers of early unplanned pregnancies. For example, U.S. fertility is at an all-time low, reaching a rate of only 1.86 children per woman of childbearing age in 2013. More importantly, fertility has reached this record low because of falling birthrates among teens and women in their early 20 s, bringing the U.S. teen pregnancy rate closer to that in other rich countries (Hamilton et al. 2013; Curtin et al. 2014). Much of this success is due to the dissemination of long-acting reversible contraceptives, which are much more effective than conventional birth control (Secura et al. 2014; Sawhill 2014).

\section{Money Makes a Difference in Parenting}

An important point established above is that money makes a difference, and especially so for young low-income children. An ever-growing number of studies have shown that refundable tax credits improve child outcomes in health, including birth

\footnotetext{
${ }^{25}$ This is more than 30 years after the then-Secretary of Education, Ted Bell, sounded the alarm in 1983 with the publication of $A$ Nation at Risk.
} 
outcomes for mothers, and the learning of young children. ${ }^{26}$ Receiving aid from the Supplemental Nutrition Assistance Program (SNAP), a program for needy families with young children, has been shown to improve childhood health and learning outcomes as well significantly reduce the incidence of "metabolic syndrome" (obesity, high blood pressure, and diabetes). For women, SNAP serves to increase economic self-sufficiency (Almond et al. 2011; Hoynes et al. 2012). More generally, supplementing incomes for low-income families with children has a large number of positive effects, as summarized by Duncan et al. (2011), Duncan (2014), and Cooper and Stewart (2013). Specifically, cash transfers from the child tax credit and earned income tax credit (EITC) and SNAP of perhaps $\$ 1500$ to $\$ 2000$ per child per year lead to better outcomes for children and parents, especially longer-term important positive developmental effects on very young children.

Building on these findings, one policy strategy is to push for a stronger EITC (including one for single adults), larger refundable child allowances, and a higher minimum wage (Sawhill and Karpilow 2014; Heinrich and Smeeding 2014a, b). Although such a package would help mitigate poverty, there is also a critical need for a labor market solution that leads to more, accessible, better-paying jobs targeted at the poor and nonpoor (see Chaps. 6 and 11).

Many low-income parents are stretched thin working in one or more low-paying jobs at odd hours, making childcare almost impossible to schedule (Reeves and Rodrigues 2014). The effects of inflexible work schedules and the lack of paid days off on a parent's ability to provide emotional and physical care for young children, as well as the detrimental effects of parental stress on children's cognitive development, are all too apparent in such situations. And so another foundational element in parental assistance would be the enforcement of the Fair Labor Standards Act so that work schedules consistent with good parenting at younger ages are planned and maintained. ${ }^{27}$

\section{Prenatal and Early Parenting Programs}

Because good parenting is so important for child outcomes, one should try to make better parents, too. But in the new policy realm of parental improvement, ideas and efforts so far outstrip evidence of success, with a few exceptions (King et al. 2013). The starting point is prenatal health, where young about-to-become-parents must learn the importance of in-utero health and the costs of some of their own habits for child outcomes (Aizer and Currie 2014). The Nurse Home Visiting Program has been shown to be highly effective when properly deployed and when follow-up to emergent home-based problems is coordinated with local social service agencies

\footnotetext{
${ }^{26}$ For a nice summary see Duncan et al. 2014; also see Evans and Garthwaite 2014; Hoynes et al. 2012; Dahl and Lochner 2012; Milligan and Stabile 2009.

${ }^{27}$ Lest we forget, the U.S. is the only rich nation without some form of national paid family leave post childbirth.
} 
(Annie E. Casey Foundation 2014; Haskins et al. 2009; Mosle et al. 2014). Still, substantial systematic differences exist in children's home learning experiences, and the few existing parenting programs that have shown promise often are not widely accessible, either due to the demands they place on parents' time and effort or cost. The widespread use, low cost, and ease of scalability of text messaging make it an attractive approach to support parenting practices (York and Loeb 2014). One exemplar program that seems to clearly make a difference in mobility and parenting just about the time of preschool is the Home Instruction for Parents of Preschool Youngsters (HIPPY) program for lower-income families with children ages 3-5. The program seeks to effectively train parents to be their child's first teacher while at the same time reducing child hyperactivity. Rigorous evaluations in New York found that the program significantly improved child reading scores (Sawhill and Karpilow 2014).

\section{The Role of the Pediatrician}

A second major type of parental-child intervention is centered on pediatricians and their role in early childhood development. The pediatrician and the parent are the bedrock of early child health and development. It is therefore essential that the physician treat the child and the parent as a single entity. Uncovering basic health issues, from allergies and asthma to hearing loss or diabetes, each require not only early detection but also successful chronic-care interventions. The burden of the habitual behaviors needed to overcome childhood asthma, for instance, requires competent parenting and regular application of medicine, cleanliness, and a host of other tasks. But that care management cannot be effectively delivered if a parent suffers from depression or high levels of stress. Health care targeting two generations at once holds the promise to improve both child outcomes and parent responsiveness to disease management programs, especially when that care is linked to social support services delivered by programs like the Nurse Home Visiting Program (Glied and Oellerich 2014). Pediatricians are often well positioned to assess children's wellbeing but usually do not ask about parental risk factors to children's health, such as smoking. One example is the SEEK Project, which trains health professionals to screen for parental risk factors and then refer the family to appropriate resources to address the problems. 


\section{Preschool: The Importance of Quality}

In addition to cognitive training, there is overlap in skills training for the labor market and family formation among children and parents alike. Soft skills such as conflict resolution or how to respond to setbacks should be emphasized more in preschools and in parenting classes (Cunha and Heckman 2007, 2008). Because we do not yet have a good substitute for Head Start, we need to improve the model (Barnett 2011). One way to expand childcare may be to make such care more affordable through new, targeted subsidies for early childhood care (Ziliak 2014). A closer look at the programs that seem to work best in Boston and Chicago is a good starting point.

\section{Conclusion}

Americans have always been more tolerant of income inequality than their European forbearers; perhaps this was because the average standard of living was increasing across the board and because the "rising tide was lifting all boats." Americans also believed that inequality was acceptable because there was lots of movement up and down the income ladder. If one worked hard and followed the rules, he or she had a good chance of rising to the top (the "Horatio Alger" ideal). But the U.S. now faces a fourfold threat: stagnant growth in standards of living for all below the top rungs of the income ladder; a growing gap between the rich and the rest; high rates of early unplanned children by parents who are not prepared to raise them, and low rates of upward mobility that threaten belief in equality of opportunity.

Nowhere is this more apparent than in the recent patterns of uneven child development at early ages. To paraphrase Robert Putnam (2015), "our kids" are not doing well and need help to succeed. Larger majorities do not believe their children's generation will be as well off as they were. If we are to restore opportunity and improve upward mobility in the United States, we need to start very young and we need to begin right now. 


\section{Appendix}

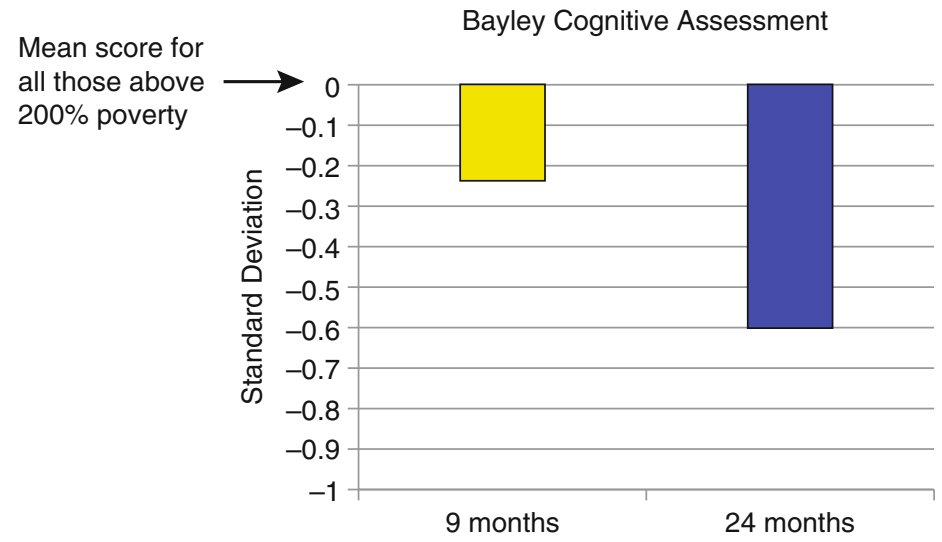

Mean score for

Positive Behavior Index

all those above $200 \%$ poverty

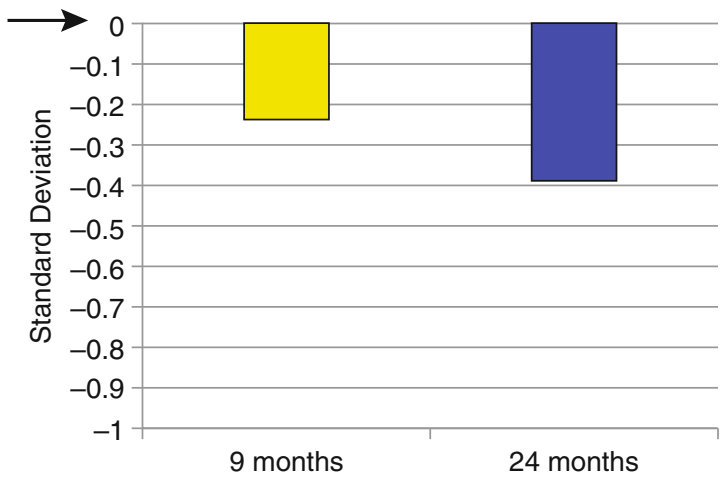

Fig. 8A.1 Disparities in cognitive and socio-behavioral outcomes by income level at 9 and 24 months (Source: Disparities in Early Learning and Development: Lessons from the Early Childhood Longitudinal Study - Birth Cohort (ECLS-B) - Executive Summary by Halle, Tamara, and Nicole Forry. Reproduced with permission of Child Trends Inc. in the format Republish in a book via Copyright Clearance Center) 


\section{Bayley Cognitive Assessment}

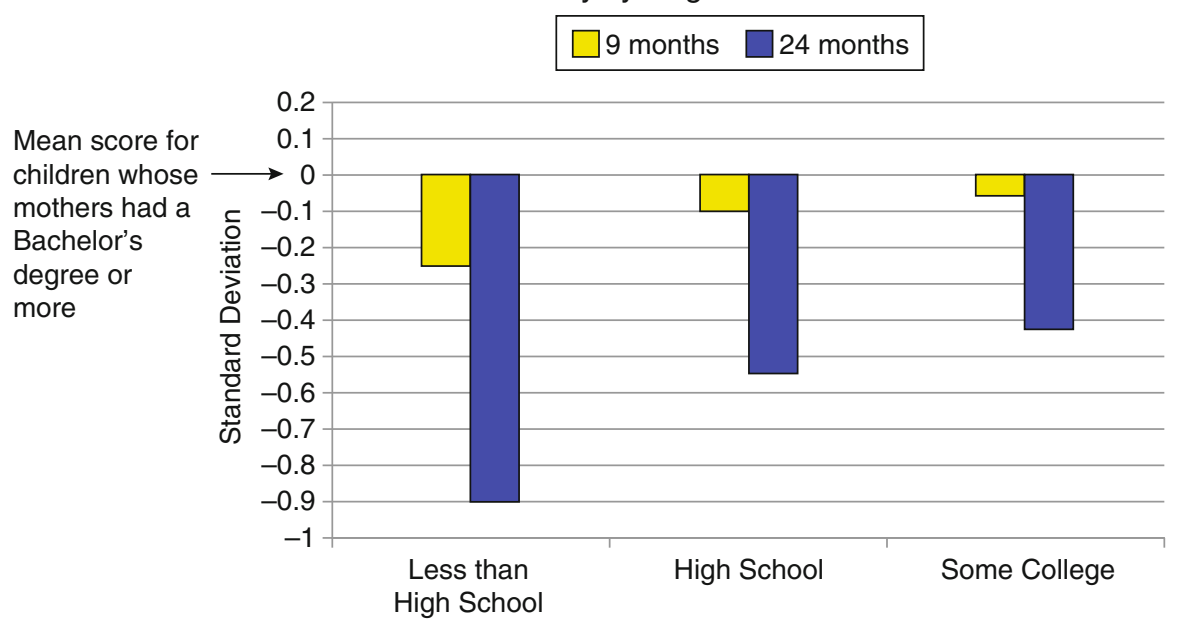

Fig. 8A.2 Disparities in cognitive and socio-behavioral outcomes by education of mother (Source: Disparities in Early Learning and Development: Lessons from the Early Childhood Longitudinal Study - Birth Cohort (ECLS-B) - Executive Summary by Halle, Tamara, and Nicole Forry. Reproduced with permission of Child Trends Inc. in the format Republish in a book via Copyright Clearance Center)

Open Access This chapter is distributed under the terms of the Creative Commons AttributionNoncommercial 2.5 License (http://creativecommons.org/licenses/by-nc/2.5/) which permits any noncommercial use, distribution, and reproduction in any medium, provided the original author(s) and source are credited.

The images or other third party material in this chapter are included in the work's Creative Commons license, unless indicated otherwise in the credit line; if such material is not included in the work's Creative Commons license and the respective action is not permitted by statutory regulation, users will need to obtain permission from the license holder to duplicate, adapt or reproduce the material.

\section{References}

Acs, Gregory. 2011. Downward mobility from the middle class: Waking up from the American dream, Pew Charitable Trusts, Economic Mobility Project, September.

Aizer, Anna, and Flávio Cunha. 2012. The production of human capital: Endowments, investments and fertility, NBER Working Paper 18429. Cambridge, MA: National Bureau of Economic Research.

Aizer, Anna, and Janet V. Currie. 2014. The intergenerational transmission of inequality: Maternal disadvantage and health at birth. Science 344(May): 856.

Aizer, Anna, Laura Stroud, and Stephen Bubka. 2012. Maternal stress and child outcomes: Evidence from siblings, NBER Working Paper 18422. Cambridge, MA: National Bureau of Economic Research.

Almond, Douglas, and Janet Currie. 2011. Killing me softly: The fetal origins hypothesis. Journal of Economic Perspectives 25(3): 153-172. doi:10.1257/jep.25.3.153. 
Almond, Douglas, and Bhashkar Mazumder. 2011. Health capital and the prenatal environment: The effects of Ramadan observance during pregnancy. American Economic Journal: Applied Economics 3(4): 56-85.

Almond, Douglas, Hilary W. Hoynes, and Diane W. Schanzenbach. 2011. Inside the war on poverty: The impact of food stamps on birth outcomes. The Review of Economics and Statistics 93(2): 387-403.

Almond, Douglas, Janet Currie, and Mariesa Herrmann. 2012. From infant to mother: Early disease environment and future maternal health. Labour Economics 19(4): 475-483.

Amato, Paul, Alan Booth, Susan McHale, and Jennifer Van Hook. 2014. Families in an era of increasing inequality: Diverging destinies Springer International Publishing, Vol. 5 of National Symposium on Family Issues, October 23.

Annie E. Casey Foundation. 2014. Creating opportunity for families: A two-generation approach. KIDS COUNT Policy Reports. Baltimore: Annie E. Casey Foundation (November 12). http:// www.aecf.org/resources/creating-opportunity-for-families/?utm_source=datacenter\&utm _ medium=web\&utm_campaign=two\%20gen\%20report\&utm_content=publications.

Autor, David H. 2014. Skills, education, and the rise of earnings inequality among the "other 99 percent'. Science 344(6186): 843-851.

Barker, David. 1995. Fetal origins of coronary heart disease. British Medical Journal 311: 171. doi: http://dx.doi.org/10.1136/bmj.311.6998.171.

Barnett, W. Steven. 2011. Effectiveness of early educational intervention. Science 333(6045): 975-978.

Becker, Gary S., and Nigel Tomes. 1979. An equilibrium theory of the distribution of income and intergenerational mobility. Journal of Political Economy 87(December): 1153-1189.

Becker, Gary S., and Nigel Tomes. 1986. Human capital and the rise and fall of families. Journal of Labor Economics 4(July): S1-S39.

Beller, Emily. 2009. Bringing intergenerational social mobility research into the twenty-first century: Why mothers matter. American Sociological Review 74: 507-528.

Bernier, Annie, Stephanie M. Carlson, and Natasha Whipple. 2010. From external regulation to self-regulation: Early parenting precursors of young children's executive functioning. Child Development 81(1): 326-339.

Bingley, Paul, and Niels Westergaard-Nielsen. 2012. Intergenerational transmission and day care. In Ermisch et al. 2012, 190-204.

Blanden, Jo., Robert Haveman, Timothy Smeeding, and Kathryn Wilson. 2014. Intergenerational mobility in the United States and Great Britain: A comparative study of parent-child pathways. Review of Income and Wealth 60(3): 425-449.

Bono, Del, John Ermisch Emilia, and Marco Francesconi. 2012. Intrafamily resource allocations: A dynamic structural model of birth weight. Journal of Labor Economics 30: 657-706.

Boyce, Thomas W. 2012. A biology of misfortune: How social stratification, sensitivity, and stress diminish early health and development. Institute for Research on Poverty New Perspectives Lecture, University of Wisconsin-Madison, February 8. http://www.irp.wisc.edu/publications/ focus/pdfs/foc291.pdf.

Bradbury, Bruce, Miles Corak, Jane Waldfogel, and E. V. Washbrook. 2012. Inequality in early childhood outcomes. In Ermisch et al. 2012.

Brodmann, Stephanie, and Douglas Massey. 2014. Spheres of influence: The social ecology of racial and class inequality. New York: Russell Sage.

Brownstein, Ronald, and Paul Taylor. 2014. The next America: Boomers, millennials, and the looming generational showdown. Philadelphia: Perseus Books.

Camilli, Gregory, Sadako Vargas, Sharon Ryan, and W. Steven Barnett. 2010. Meta-analysis of the effects of early education interventions on cognitive and social development. Teachers College Record 112(3): 579-620.

Carlson, Marcia, and Daniel R. Meyer (eds.). 2014. Family complexity. The Annals of the American Academy of Political and Social Science, July.

Carneiro, Pedro, and Rita Ginja. 2014. Long-term impacts of compensatory preschool on health and behavior: Evidence from Head Start. American Economic Journal: Economic Policy 6(4): 135-173. 
CBO (Congressional Budget Office). 2011. The distribution of income and federal taxes. Washington,DC:http://www.cbo.gov/sites/default/files/cbofiles/attachments/49440-Distributionof-Income-and-Taxes.pdf.

Champagne, Frances A., and Rahia Mashoodh. 2009. Genes in context gene-environment interplay and the origins of individual differences in behavior. Current Directions in Psychological Science 18(3): 127-131.

Cherlin, Andrew J. 2014. Labor's love lost: The rise and fall of the working-class family in America. New York: Russell Sage.

Chetty, Raj, John Friedman, Nathaniel Hilger, Emmanuel Saez, Diane Schanzenbach, and Danny Yagan. 2011. How does your kindergarten classroom affect your earnings? Evidence from Project STAR. Quarterly Journal of Economics 126(4): 1593-1660.

Chetty, Raj, and Nathaniel Hendren. 2015. The impacts of neighborhoods on intergenerational mobility: Childhood exposure effects and county-level estimates. Cambridge, MA: Harvard University and National Bureau of Economic Research. http://scholar.harvard.edu/files/hendren/files/nbhds_paper.pdf.

Chetty, Raj, Nathaniel Hendren, Patrick Kline, and Emmanuel Saez. 2014. Where is the land of opportunity? The geography of intergenerational mobility in the United States. Quarterly Journal of Economics 129(4): 1553-1623.

Cooper, Kerris, and Kitty Stewart. 2013. Does money affect children's outcomes? A systematic review. York: Joseph Rowntree Foundation, October. http://sticerd.lse.ac.uk/dps/case/cr/casereport80.pdf.

Costa, Kristina. 2014. Fact sheet: Social impact bonds in the United States. Washington, DC: Center for American Progress, February 12. https://www.americanprogress.org/issues/economy/report/2014/02/12/84003/fact-sheet-social-impact-bonds-in-the-united-states/.

Cunha, Flavio, and James J. Heckman. 2007. The technology of skill formation. American Economic Review 97(May): 31-47.

Cunha, Flavio, and James J. Heckman. 2008. Formulating, identifying and estimating the technology of cognitive and noncognitive skill formation. Journal of Human Resources 43: 738-782.

Cunha, Flavio, James J. Heckman, and Susanne M. Schennach. 2010. Estimating the technology of cognitive and noncognitive skill formation. Econometrica 78(3): 883-931.

Currie, Janet, Matthew J. Neidell, and Johannes F. Schmieder. 2009. Air pollution and infant health: Lessons from New Jersey. Journal of Health Economics 28(3): 688-703.

Currie, Janet, and Reed Walker. 2011. Traffic congestion and infant health: Evidence from E-ZPass. American Economic Journals-Applied Microeconomics 3(January): 65-90.

Curtin, Sally C., Stephanie J. Ventura, and Gladys M. Martinez. 2014. Recent declines in nonmarital childbearing in the United States, NCHS Data Brief No. 162. U.S. Centers for Disease Control, National Center for Health Statistics, August. http://www.cdc.gov/nchs/data/databriefs/db162.pdf.

Dahl, Gordon B., and Lance Lochner. 2012. The impact of family income on child achievement: Evidence from the earned income tax credit. American Economic Review 102: 1927-1956.

Dumas, Christtelle, and Arnaud Lefranc. 2012. Early schooling and later outcomes. In Ermisch et al. 2012.

Duncan, Brian, and Stephen J. Trejo. 2015. Assessing the socioeconomic mobility and integration of U.S. immigrants and their descendants. In Grusky, Smeeding, and Snipp 2015, 108-134.

Duncan, Greg. 2014. Optimal preschool policies for low-income children. Presented to the University of Wisconsin-Madison, Institute for Research on Poverty seminar series, September 18.

Duncan, Greg J., and Katherine Magnuson. 2011. The nature and impact of early achievement skills, attention and behavior problems. In Duncan and Murnane 2011, 47-69.

Duncan, Greg J., and Katherine Magnuson. 2013. Investing in preschool programs. Journal of Economic Perspectives 27(2): 109-131.

Duncan, Greg J., Katherine Magnuson, and Elizabeth Votruba-Drzal. 2014. Boosting family income to promote child development. Future of Children 24(1): 99-120. 
Duncan, Greg J., Pamela Morris, and Chris Rodrigues. 2011. Does money really matter? Estimating impacts of family income on young children's achievement with data from random-assignment experiments. Developmental Psychology 47: 1263-1279. doi:10.1037/a0023875.

Duncan, Greg J., and Richard J. Murnane. 2011. Whither opportunity: Rising inequality, schools, and children's life chances. New York: Russell Sage Foundation/Spencer Foundation.

Duncan, Greg J., and Richard J. Murnane. 2013. Restoring opportunity: The crisis of inequality and the challenge for American education. Cambridge, MA: Harvard Education.

Edin, Kathryn, Stefanie DeLuca, and Ann Owens. 2012. Constrained compliance: Solving the mystery of MTO lease-up rates and why mobility matters. Cityscape 14(2): 181-194.

Ehrlich, Stacy B., Julia A. Gwynne, Amber Stitziel Pareja, and Elaine M. Allensworth. 2013. Preschool attendance in Chicago public schools: Relationships with learning outcomes and reasons for absences: Research summary. Chicago: University of Chicago, September. https:// ccsr.uchicago.edu/publications/preschool-attendance-chicago-public-schools-relationshipslearning-outcomes-and-reasons.

Ermisch, John M., Markus Jäntti, and Timothy M. Smeeding. 2012. From parents to children: The intergenerational transmission of advantage. New York: Russell Sage.

Essex, Marilyn J., W. Thomas Boyce, Clyde Hertzman, Lucia L. Lam, Jeffrey M. Armstrong, Sarah M.A. Neumann, and Michael S. Kobor. 2013. Epigenetic vestiges of early developmental adversity: Childhood stress exposure and DNA Methylation in adolescence. Child Development 84(1): 58-75.

Evans, William N., and Craig L. Garthwaite. 2014. Giving mom a break: The impact of higher EITC payments on maternal health. American Economic Journal: Economic Policy 6(2): 258-290.

Figlio, David, Jonathan Guryan, Krzysztof Karbownik, and Jeffrey Roth. 2014. The effects of poor neonatal health on children's cognitive development. American Economic Review 104(December): 3921-3955.

Fisher, Jonathan, David Johnson, Timothy Smeeding, and Jeffrey Thompson. 2015. The demography of inequality: Income, wealth and consumption, 1989-2010. Working paper. Presented to the Population Association of America, April.

Fox, Nathan A., Pat Levitt, and Charles A. Nelson. 2010. How the timing and quality of early experiences influence the development of brain architecture. Child Development 81(1): 28-40.

Frey, William H. 2014. Diversity explosion: How new racial demographics are remaking America. Washington, DC: Brookings Institution Press.

Galston, William A. 2014. Declining optimism among the Obama coalition. 2014. Washington, DC: Brookings Institution, September 23. http://www.brookings.edu/blogs/fixgov/ posts/2014/09/23-american-values-survey-american-dream-galston?.

Glied, Sherry, and Don Oellerich. 2014. Two-generation programs and health. Future of Children 24(1): 79-97.

Grusky, David, Timothy Smeeding, and C. Matthew Snipp. 2015. Monitoring social mobility in the 21st century. Annals of the American Academy of Political and Social Science 657 (January).

Guryan, Jonathan, Erik Hurst, and Melissa S. Kearney. 2008. Parental education and parental time with children. Journal of Economic Perspectives 22(3): 23-46.

Halle, Tamara, Nicole Forry, Elizabeth Hair, Kate Perper, Laura Wandner, Julia Wessel, and Jessica Vick. 2009. Disparities in early learning and development: Lessons from the Early Childhood Longitudinal Study-Birth Cohort (ECLS-B). Washington, DC: Child Trends.

Hamermesh, Daniel, and Elizabeth Stancanelli. 2014. Long workweeks and strange hours. IZA DP No. 8423, August. Bonn: Institute for the Study of Labor. http://ftp.iza.org/dp8423.pdf.

Hamilton, Brady, Joyce A. Martin, Michelle J. K. Osterman, and Sally C. Curtin. 2013. Births: Preliminary data for 2013 National vital statistics reports 63, No 2. May 29. U.S. Centers for Disease Control, National Center for Health Statistics http://www.cdc.gov/nchs/data/nvsr/ nvsr63/nvsr63_02.pdf.

Hanson, Jamie L., Nicole Hair, Dinggang Shen, Feng Shi, John H. Gilmore, Barbara L. Wolfe, and Seth D. Pollak. 2013. Family poverty affects the rate of human infant brain growth. PLOS One 8 (December 11): doi:10.1371/journal.pone.0080954. 
Hanson Jamie L., Brendon M. Nacewicz, Matthew J. Sutterer, Amelia A. Cayo, Stacey M. Schaefer, Karen D. Rudolph, Elizabeth A. Shirtcliff, Seth D. Pollak, and Richard J. Davidson. 2014. Behavior problems after early life stress: Contributions of the hippocampus and amygdala. Biological Psychiatry. doi:10.1016/j.biopsych.2014.04.020.

Haskins, Ron, Christina Paxson, and Jeanne Brooks-Gunn. 2009. Social science rising: A tale of evidence shaping public policy, Future of Children, Policy Brief. Princeton: Princeton University. http://futureofchildren.org/futureofchildren/publications/docs/19_02_PolicyBrief.pdf.

Heckman, James J. 2012. Hard evidence on soft skills, Lampman Lecture, University of WisconsinMadison, Institute for Research on Poverty, May. http://www.irp.wisc.edu/newsevents/other/ lampman/2012Lampman-Heckman.pdf.

Heckman, James J., and Tim Kautz. 2014. Fostering and measuring skills: Interventions that improve character and cognition. In The myth of achievement tests: The GED and the role of character in American life, ed. J.J. Heckman, J.E. Humphries, and Tim Kautz, 293-317. Chicago: University of Chicago Press.

Heckman, James J., and Stefano Mosso. 2014. The economics of human development and social mobility. Annual Review of Economics 6: 689-733.

Heckman, James, Rodrigo Pinto, and Peter Savelyev. 2013. Understanding the mechanisms through which an influential early childhood program boosted adult outcomes. American Economic Review 103(6): 2052-2086. http://dx.doi.org/10.1257/aer.103.6.2052.

Heinrich, Carolyn, and Timothy Smeeding. 2014a. Building human capital and economic potential, Fast Focus No. 21-2014, Institute for Research on Poverty, University of WisconsinMadison, September. http://www.irp.wisc.edu/publications/fastfocus/pdfs/FF21-2014.pdf.

Heinrich, Carolyn, and Timothy Smeeding. 2014b. Building economic self-sufficiency, Focus on Policy No. 2, Institute for Research on Poverty, University of Wisconsin-Madison, September. http://www.irp.wisc.edu/publications/policybriefs/pdfs/PB2-SelfSufficiency.pdf.

Hoynes, Hilary, Diane Whitmore Schanzenbach, and Douglas Almond. 2012. Long run impacts of childhood access to the safety net, NBER Working Paper 18535. Cambridge, MA: National Bureau of Economic Research, November. http://www.nber.org/papers/w18535.

Hsin, Amy. 2012. Is biology destiny? Birth weight and differential parental treatment. Demography 49(4): 1385-1405.

Jäntti, Markus, Brent Bratsberg, Knut Reed, Oddbjørn Raaum, Robin Naylor, Eva Österbacka, Anders Björklund, and Tor Eriksson. 2006. American exceptionalism in a new light: A comparison of intergenerational earnings mobility in the Nordic countries, the United Kingdom and the United States, IZA Discussion Papers 1938, Institute for the Study of Labor.

Jencks, Christopher, and Laura Tach. 2006. Would equal opportunity mean more mobility? In Mobility and inequality: Frontiers of research from sociology and economics, ed. Stephen B. Morgan, David L. Grusky, and Gary S. Fields. Stanford: Stanford University Press.

Jones, Robert P., Daniel Cox, and Juhem Navarro-Rivera. 2014. Economic insecurity, rising inequality, and doubts about the future: Findings from the 2014 American values survey. Washington, DC: Public Religion Research Institute, September 23. http://publicreligion.org/ site/wp-content/uploads/2014/09/AVS-web.pdf.

Kalil, Ariel, Rebecca Ryan, and Michael Corey. 2012. Diverging destinies: Maternal education and the developmental gradient in time with children. Demography 49: 1361-1383.

Kaushal, Neeraj, Katherine Magnuson, and Jane Waldfogel. 2011. How is family income related to investments in children's learning? In Duncan and Murnane 2011, 187-206.

Kautz, Tim, James Heckman, Ron Diris, Baster Weel, and Lex Borghans. 2014. Fostering and measuring skills: Improving cognitive and non-cognitive skills to promote lifetime success. Paris: OECD. http://www.oecd.org/edu/ceri/Fostering-and-Measuring-Skills-Improving-Cognitive-and-Non-Cognitive-Skills-to-Promote-Lifetime-Success.pdf.

Kenworthy, Lane, and Timothy Smeeding. 2014. The United States: High and rapidly-rising inequality. In Inequality and its impacts, vol. 2, ed. Brian Nolan, Wiemer Salverda, Daniele Checchi, Ive Marx, Abigail McKnight, István György Tóth, and Herman G. van de Werfhorst, 695-717. Oxford: Oxford University Press. 
King, Christopher T., Rheagan Coffey, and Tara C. Smith. 2013. Promoting two-generation strategies: A getting started guide for state and local policy makers. Austin: University of TexasatAustinLBJSchoolofPublicAffairs.http://fcd-us.org/resources/promoting-two-generationstrategies-getting-started-guide-state-and-local-policy-makers.

Kirkegaard, Jacob F. 2015. The true levels of government and social expenditures in advanced economies, Peterson Institute, Policy Brief 15-4, Washington DC, March. http://www.piie. com/publications/pb/pb15-4.pdf.

Kneebone, Elizabeth. 2014. The growth and spread of concentrated poverty, 2000 to 2008-2012, Brookings Metropolitan Studies Research Brief. Washington, DC: Brookings Institution, July 31. http://www.brookings.edu/research/interactives/2014/concentrated-poverty\#/M10420.

Knudsen, Eric I., James J. Heckman, Judy L. Cameron, and Jack P. Shonkoff. 2006. Economic, neurobiological, and behavioral perspectives on building America's future workforce. Proceedings of the National Academy of Sciences.

Landry, Susan, Karen Smith, and Paul Swank. 2006. Responsive parenting: Establishing early foundations for social, communication, and independent problem-solving skills. Developmental Psychology 42(4): 627-642.

Liebman, Jeffrey. Social impact bonds. 2011. Washington, DC: Center for American Progress, February 9. https://www.americanprogress.org/wp-content/uploads/issues/2011/02/pdf/social_ impact_bonds.pdf.

Lien, Diana Stech, and William N. Evans. 2005. Estimating the impact of large cigarette tax hikes: The case of maternal smoking and low birth weight. Journal of Human Resources 40(2): 373-392.

Lundberg, Shelly, and Robert Pollak. 2013. Cohabitation and the uneven retreat from marriage in the United States: 1950-2010, NBER Working Paper 19413, Cambridge, MA: National Bureau of Economic Research. http://www.nber.org/papers/w19413.

Magnuson, Katherine, and Greg J. Duncan. 2014. Can early childhood interventions decrease inequality of economic opportunity? Presented to the Federal Reserve Bank of Boston Conference, Inequality of Economic Opportunity in the United States, October 17-18.

Magnuson, Katherine, and Jane Waldfogel. 2005. Early childhood care and education: Effects on ethnic and racial gaps in school readiness. Future of Children 15(1): 169-196.

Magnuson, Katherine, Claudia Lahaie, and Jane Waldfogel. 2006. Preschool and school readiness of children of immigrants. Social Science Quarterly 87: 1241-1262.

Magnuson, Katherine, Jane Waldfogel, and E.V. Washbrook. 2012. The development of SES gradients in skills during the school years: Evidence from the U.S. and U.K. In Ermisch et al. 2012.

Mazumder, Bhashkar. 2014. Black-White differences in intergenerational economic mobility in the United States. Economic Perspectives 38(1): 1-18.

Mazumder, Bhashkar. 2015. Estimating the intergenerational elasticity and rank association in the US: Overcoming the current limitations of tax data. Chicago: Federal Reserve Bank of Chicago, April. http://www.iza.org/conference_files/inequality_2015/mazumder_b3665.pdf.

Mazumder, Bhashkar, Douglas Almond, Kathleen Parka, Eileen M. Crimmins, and Caleb E. Finch. 2010. Lingering prenatal effects of the 1918 Influenza Pandemic on Cardiovascular disease. Journal of Developmental Origins of Health and Disease 1(February): 26-34.

Mazumder, Bhashkar, Douglas Almond, and Reyn Van Ewijk. 2015. Fasting during pregnancy and children's academic performance. Economic Journal.

McCall, Leslie, and Derek Burk. 2014. Beyond the work-income debate: Gender and class inequalities in resource pooling. Presented to the Plenary Panel of the Complex Inequalities and Global Dimensions of Gender Conference, University of Stockholm, June.

McEwen, Bruce S., and Peter J. Gianaros. 2010. Central role of the brain in stress and adaptation: Links to socioeconomic status, health, and disease. Annals of the New York Academy of Sciences 1186: 190-222.

McLanahan, Sara. 2014. Family and mobility. Presentation to the U.S. Administration for Children and Families seminar on Intergenerational Socials and Economic Mobility, Washington, DC, May 16. 
McLanahan, Sara, and Wade Jacobsen. 2013. Diverging destinies revisited. Draft presentation for Penn State University conference, August 16.

Milligan, Kevin, and Mark Stabile. 2009. Child benefits, maternal employment, and children's health: Evidence from Canadian child benefit expansions. American Economic Review 99(2): 128-132.

Mishel, Lawrence. 2013. Trends in U.S. work hours and wages over 1979-2007, Issue Brief 348, January 30. Washington, DC: Economic Policy Institute. http://www.epi.org/publication/ ib348-trends-us-work-hours-wages-1979-2007/.

Mood, Carina, Jan O. Jonsson, and Erik Bihagen. 2012. Socioeconomic persistence across generations: Cognitive and noncognitive processes. In Ermisch et al. 2012, 53-84.

Mosle, Anne, Nisha Patel, and Jennifer Stedron. 2014. The top ten for 2gen, Ascend. Washington, DC: Aspen Institute, October. http://b.3cdn.net/ascend/1b324c19707d1e43c6_p4m6i2zji.pdf.

Murray, Charles. 2012. Coming apart: The state of White America, 1960-2010. New York: Crown Publishing.

Noble, Kimberly G., Suzanne M. Houston, Natalie H. Brito, Bartsch Hauke, Kan Eric, Joshua M. Kuperman, Akshoomon Natacha, David G. Amaral, Cinnamon S. Bloss, Libiger Ondrej, Nicholas J. Schork, Sarah S. Murray, B.J. Casey, Chang Linda, Thomas M. Ernst, Jean A. Frazier, Jeffrey R. Gruen, David N. Kennedy, Peter Van Zijl, Mostofsky Stewart, Walter E. Kaufmann, Kenet Tal, Anders M. Dale, Terry L. Jerniga, and Elizabeth R. Sowell. 2015. Family income, parental education and brain structure in children and adolescents. Nature Neuroscience 18: 773-778. doi:10.1038/nn.3983.

OECD (Organisation for Economic Co-operation and Development). 2014. Education at a glance-U.S. Country note. Paris: Author. http://www.oecd.org/edu/United\%20StatesEAG2014-Country-Note.pdf.

OECD. 2015. Public spending on childcare and early education. OECD Family Database- Social Policy Division - Directorate of Employment, Labour and Social Affairs, PF3.1. http://www. oecd.org/els/soc/PF3_1_Public_spending_on_childcare_and_early_education.pdf.

Pfeffer, Fabian. 2011. Status attainment and wealth in the United States and Germany. In Persistence, privilege, and parenting: The comparative study of intergenerational mobility, ed. Timothy Smeeding, Robert Erikson, and Markus Jäntti. New York: Russell Sage.

Pfeffer, Fabian T., and Martin Hällsten. 2012. Mobility regimes and parental wealth: The United States, Germany, and Sweden in comparison, Population Studies Center Research Report 12-766. http://www.psc.isr.umich.edu/pubs/abs/7676.

Phillips, Meredith. 2011. Parenting, time use, and disparities in academic outcomes. In Duncan and Murnane 2011.

Putnam, Robert. 2015. Our kids: The American dream in crisis. New York: Simon and Schuster.

Quinn, Sandra Crouse, Supriya Kumar, Vicki S. Freimuth, Donald Musa, Nestor CastenedaAngarita, and Kelley Kidwell. 2011. Racial disparities in exposure, susceptibility, and access to health care in the U.S. H1N1 Influenza Pandemic. American Journal of Public Health 101(2): 285-293.

Reardon, Sean. F. 2011. The widening academic achievement gap between the rich and the poor: New evidence and possible explanations. In Duncan and Murnane 2011.

Reeves, Richard. 2013. The glass floor. Washington, DC: Brookings Institution, November. http:// www.brookings.edu.

Reeves, Richard. 2014. Equality, opportunity, and the American dream. National Journal (August 14). http://www.nationaljournal.com/economy/equality-opportunity-and-the-american-dream20140820.

Reeves, Richard, and Kimberly Howard. 2013. The parenting gap. Washington, DC: Brookings Institution. http://www.brookings.edu.

Reeves, Richard, and Edward Rodrigue. 2014. Do unpredictable hours undermine upward mobility? Washington, DC: Brookings Institution, December 11. http://www.brookings.edu.

Roberts, Brian W., Carl Lejuez, Robert F. Krueger, Jessica M. Richards, and Patrick L. Hill. 2014. What is conscientiousness and how can it be assessed? Developmental Psychology 50(5): $1315-1330$. 
Rowe, Meredith L. 2012. A longitudinal investigation of the role of quantity and quality of child-directed speech in vocabulary development. Child Development 83: 1762-1774.

Sabol, Terri J., and P. Lindsay Chase-Lansdale. 2015. The influence of low-income children's participation in Head Start on their parents' education and employment. Journal of Policy Analysis and Management 34(Winter): 136-161.

Sameroff, Arnold. 2010. A unified theory of development: A dialectic integration of nature and nurture. Child Development 81(1): 6-22.

Sanders, Nicholas J. 2012. What doesn't kill you makes you weaker: Prenatal pollution exposure and educational outcomes. Journal of Human Resources 47: 826-850.

Sawhill, Isabel. 2010. Do we face a permanently divided society? Presented at Tobin Project Conference on Democracy and Markets: Understanding the Effects of America's Economic Stratification, April 30-May 2, 2010. http://www.tobinproject.org/sites/tobinproject.org/files/ assets/Sawhill\%20\%20Do\%20we\%20face\%20a\%20permanently\%20divided\%20society.pdf.

Sawhill, Isabel. 2014. Generation unbound: Drifting into sex and parenthood without marriage. Washington, DC: Brookings Institution Press, September.

Sawhill, Isabel, and Quentin Karpilow. 2014. Raising the minimum wage and redesigning the EITC. Washington, DC: Brookings Institution, January 30, http://www.brookings.edu/research/ papers/2014/01/30-raising-minimum-wage-redesigning-eitc-sawhill.

Secura, Gina M., Tessa Madden, Colleen McNicholas, Jennifer Mullersman, Christina M. Buckel, Qiuhong Zhao, and Jeffrey F. Peipert. 2014. Provision of no-cost, long-acting contraception and teenage pregnancy. New England Journal of Medicine 371(October 2): 1316-1323. doi:10.1056/NEJMoa1400506.

Seeman, Teresa, Elissa Epel, Tara Gruenewald, Arun Karlamangla, and Bruce S. McEwen. 2010. Socio-economic differentials in peripheral biology: Cumulative allostatic load. Annals of the New York Academy of Sciences 1186(February): 223-239. doi:10.1111/j.1749-6632.2009.05341.x.

Seshadri, Ananth, Sang Yoon (Tim) Lee, and Nicolas Roys. 2014. The causal effect of parental human capital on children's human capital, working paper, University of Wisconsin-Madison, Economics Department, October.

Shapiro, Robert. 2015. Income growth and decline under recent U.S. Presidents and the new challenge to restore broad economic prosperity. Washington, DC: Brookings Institution, March 5. http://www.brookings.edu/research/papers/2015/03/05-income-growth-decline-economicprosperity-shapiro.

Sharkey, Patrick. 2013. Stuck in place: Urban neighborhoods and the end of progress toward racial equality. Chicago: University of Chicago Press.

Shonkoff, Jack P. 2010. Building a new biodevelopmental framework to guide the future of early childhood policy. Child Development 81(1): 357-367.

Shonkoff, Jack P., Andrew S. Garner, The Committee on Psychosocial Aspects of Child and Family Health, Committee on Early Childhood, Adoption, and Dependent Care, and Section on Developmental and Behavioral Pediatrics. 2012. Lifelong effects of early childhood adversity and toxic stress. Pediatrics 129: e232-e246.

Smeeding, Timothy. 2014. Social mobility: Three reasons to worry about the future, Social Mobility Summit Series. Washington, DC: Brookings Institution, February 26. http://www.brookings. edu/blogs/social-mobility-memos/posts/2014/02/26-3-reasons-to-worry-about-the-future.

Smeeding, Timothy. 2015. Multiple barriers to economic opportunity in the United States. Presented to the Federal Reserve Bank of Boston Conference, Inequality of Economic Opportunity in the United States, October 17-18, 2014 (Revised).

Smeeding, Timothy M., Robert Erikson, and Markus Jäntti (eds.). 2011a. Persistence, privilege and parenting: The comparative study of intergenerational mobility. New York: Russell Sage.

Smeeding, Timothy M., Irwin Garfinkel, and Ronald Mincy (eds.). 2011b. Young disadvantaged men: Fathers, families, poverty, and policy. Annals of the American Academy of Political and Social Science 635.

Solon, Gary. 2014. Theoretical models of inequality transmission across multiple generations. Research in Social Stratification and Mobility 35(March): 13-18. 
Summers, Lawrence, and Ed Balls. 2015. Report of the commission on inclusive prosperity. Center for American Prosperity, Washington, DC, January. https://cdn.americanprogress.org/wpcontent/uploads/2015/01/IPC-PDF-full.pdf.

Tach, Laura. 2015. Social mobility in an era of family instability and complexity. In Grusky, Smeeding, and Snipp 2015, 83-96.

Takanishi, Ruby. 2004. Leveling the playing field: Supporting immigrant children from birth to eight. Future of Children 14(2): 61-79.

Torche, Florencia. 2011. Is a college degree still the great equalizer? Intergenerational mobility across levels of schooling in the U.S. American Journal of Sociology 117(3): 763-807.

Vest, Joshua R., Tegan K. Catlin, John J. Chen, and Ross C. Brownson. 2002. Multistate analysis of factors associated with intimate partner violence. American Journal of Preventative Medicine 22: 156-164.

Walters, Christopher. 2014. Inputs in the production of early childhood human capital: Evidence from Head Start, NBER Working Paper 20639. Cambridge, MA: National Bureau of Economic Research. http://www.nber.org/papers/w20639.

Wang, Wendy, and Kim Parker. 2014. Record share of Americans have never married, as values, economics and gender patterns change, Pew Research Report. Washington, DC: Pew Research, September 24. http://www.pewsocialtrends.org/2014/09/24/record-share-of-americans-havenever-married/.

Weiland, Christina, and Hirokazu Yoshikawa. 2013. Impacts of a prekindergarten program on children's mathematics, language, literacy, executive function, and emotional skills. Child Development 84(6): 2112-2130.

Weisleder, Adriana, and Anne Fernald. 2013. Talking to children matters: Early language experience strengthens processing and builds vocabulary. Psychological Science 24(11): 2143-2152.

Wilson, William Julius. 1987. The truly disadvantaged. Cambridge, MA: Harvard University Press.

Wilson, William Julius. 1996. When work disappears. New York: Knopf.

Wooten, Karen G., Pascale M. Wortley, James A. Singleton, and Gary L. Euler. 2012. Perceptions matter: Beliefs about influenza vaccine and vaccination behavior among elderly White, Black and Hispanic Americans. Vaccine 30(November 6): 6927-6934. doi:10.1016/j.vaccine.2012.08.036. Epub 2012 Aug 30.

Yellen, Janet L. 2014. Perspectives on inequality and opportunity from the survey of consumer finances. Presentation to the Conference on Economic Opportunity and Inequality, Federal Reserve Bank of Boston, October 17. http://federalreserve.gov/newsevents/speech/yellen20141017a.htm.

Yeung, W. Jean, Miriam R. Linver, and Jeanne Brooks-Gunn. 2002. How money matters for young children's development: Parental investment and family processes. Child Development 73(November-December): 1861-1879.

York, Benjamin, and Susanna Loeb. 2014. One step at a time: The effects of an early literacy text messaging program for parents of preschoolers, NBER Working Paper 20659. Cambridge, MA: National Bureau of Economic Research. http://papers.nber.org/papers/W20659.

Ziliak, James. 2014. Making child care more affordable for working families, Hamilton Project Report. Washington, DC: Brookings Institution, July 11. http://www.hamiltonproject.org/blog/ making_child_care_more_affordable_for_working_families/. 